\title{
Stem cells as a promising therapeutic approach for Alzheimer's disease: a review
}

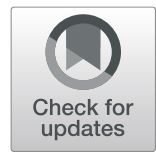

\author{
Ghadha Ibrahim Fouad(D
}

\begin{abstract}
Alzheimer's disease (AD) is a neurodegenerative disorder that impairs memory formation and disrupts neurocognitive function. This neuropathy is characterized by neural loss, neurodegeneration, and formation of amyloid plaques and neurofibrillary tangles. Approved medications provide only symptomatic relief without affecting AD progression. Because of the multifactorial nature of $A D$ and the absence of effective treatment, stem cell-based therapy has been regarded as an effective, safe, and innovative therapeutic approach to overcome AD. Different sources of stem cells are employed for AD treatment, such as neural stem cells (NSCs), mesenchymal stem cells (MSCs), embryonic stem cells (ESCs), and induced pluripotent stem cells (iPSCs). There is a growing body of evidence supporting the promising therapeutic potential of stem cell transplantation, which might be attributed to the mechanistic actions exerted by stem cells such as inducing hippocampal neurogenesis, secreting paracrine factors, exerting anti-inflammatory activity, showing anti-amyloidogenic potential, and finally resulting in cognitive recovery. Although stem cell-based therapy faces potential hurdles, it holds a potential hope to provide a safe, effective, and feasible clinical application of stem cells in AD patients.
\end{abstract}

Keywords: Stem cell-based therapy, Alzheimer's disease, Neurodegeneration, Stem cell transplantation, Neurogenesis, Mechanistic actions

\section{Background}

Alzheimer's disease (AD) is an untreatable and age-related neurodegenerative disorder responsible for 50 to $70 \%$ of all dementia cases worldwide (Zhagn and Li 2014). AD, the most common form of dementia, is clinically identified by a slowly progressive decline in neurocognitive functions because of neural and synaptic loss, and deposition of neurotoxic proteins such as extracellular senile amyloid- $\beta$ (A $\beta$ ) plaques and intracellular neurofibrillary tangles (NFTs) (Popovic and Brundin 2006). AD is a proteinopathy due to excessive accumulation of misfolded and neurotoxic proteins like hyperphosphorylated tau protein and $A \beta-42$, which leads to neurotoxicity and subsequent synaptic failure (Reitz et al. 2011). AD neuropathy is a typical example of a complex multifactorial brain disorder that is considered to some extent a "stem cell disease," as deposition of $A \beta-42$ plaques has a negative impact on stem cell proliferation, and even newly generated

Correspondence: ghadhaibrahim@yahoo.com

Department of Therapeutic Chemistry, National Research Centre, 33

El-Bohouth St., Dokki, Cairo Postal code: 12622, Egypt neurons and glia ceased to survive in an AD-related microenvironment (Tincera et al. 2016).

Therefore, regenerative therapy, using stem cells, could be regarded as a promising and safe approach for regeneration of altered or lost cellular functions (Kocaoglu et al. 2014). Although the underlying mechanisms of stem cell-based therapy need more clarification, there are several preclinical studies demonstrated encouraging results (Kwak et al. 2018). This review demonstrates $\mathrm{AD}$ pathogenesis and summarizes the relevant stem cell research, mechanistic actions, and challenges in developing different stem cells for $\mathrm{AD}$ treatment.

\section{The pathology of $A D$ and current treatment}

Alzheimer's disease (AD) is a multifactorial brain disorder, with several pathogenic factors including genetic factors, oxidative stress, $A \beta$-induced neurotoxicity, excitotoxicity, neuroinflammation, mitochondrial dysfunction, and cytoskeletal alteration of synapse components; therefore, it is complicated to determine its exact pathophysiologic cascade (Huang and Mucke 2012; Ferreiro et al. 2012). There are several assumptions that 
explain AD neuropathy such as cholinergic assumption, oxidative stress assumption, and amyloid cascade assumption (Bali et al. 2017). However, approximately one-third of $\mathrm{AD}$ patients showed no radiographic signs of amyloid plaques (Doraiswamy et al. 2014). Therefore, more advanced diagnostic approaches should be developed to enable the early diagnosis of AD (James et al. 2015; Sperling et al. 2011).

Amyloid cascade hypothesis assumed that the uncontrolled proteolytic processing of amyloid precursor protein (APP) results in the excessive accumulation of $A \beta$ deposits (Querfurth and La Ferla 2010). APP is hydrolyzed through two major pathways; the non-amyloidogenic ( $\alpha$-secretase) pathway that leads to the generation of non-pathogenic amyloid products and the amyloidogenic ( $\beta$ - and $\gamma$-secretases) pathway that results in the formation of two forms of $\mathrm{A} \beta$ peptides: predominant $\mathrm{A} \beta-40(90 \%)$ and fibrillogenic $\mathrm{A} \beta-42$ (10\%), involved in $\mathrm{AD}$ pathology (Portelius et al. 2010; Perneczky and Alexopoulos 2014; Bali et al. 2017). Accumulation of $A \beta$ plaques induces neurotoxicity and triggers a cascade of pathological events leading to neuroapoptosis in the central nervous system (CNS) (Pallas and Camins 2006; Hardy 2009), (Fig. 1).

On the other hand, Tau is an "intracellular microtubuleassociated protein" that plays an essential role in microtubule stabilization; therefore, atypical hyperphosphorylation of tau protein results in the formation of NFTs and disruption of microtubules (Khan and Bloom 2016; Bali et al. 2017). Moreover, microglial activation, and associated inflammatory mechanisms contribute to $\mathrm{AD}$ pathophysiology (Meraz-Ríos et al. 2013; Millington et al. 2014). In addition, metabolic dysfunction resulted in elevated levels of reactive oxygen species (ROS), reactive nitrogen species (RNS), and inflammatory mediators that generate neuroinflammation in $\mathrm{AD}$ subjects (Luque-Contreras et al. 2014). Another critical theory in $\mathrm{AD}$ pathogenesis is "Cholinergic hypothesis," which describes the impairment of cholinergic neurotransmission and the selective deficiency of the neurotransmitter acetylcholine (ACh) in AD brains (Zivin and Pregelj 2008).

Based on etiology, they are two classes of $\mathrm{AD}$ : early-onset familial (FAD)-approximately $10 \%$ of the cases-and late-onset sporadic (SAD) - $90 \%$ of the cases (Bekris et al. 2010). Familial AD (FAD) is a very rare autosomal dominant $\mathrm{AD}$ disorder that affects patients under the age of 65 years (Amemori et al. 2015), its early onset is associated with mutations in specific genes such as APP, presenilin 1 (PS1), and presenilin 2 (PS2) (Bekris et al. 2010; Schipper 2011). Sporadic AD (SAD) appears to have a complex genetic profile and interacting environmental factors (Alzheimer's Association 2016). SAD is characterized by deposition of extracellular $A \beta$ plaques, hyperphosphorylation of tau, microglial activation, and finally the massive neuronal and synaptic loss, resulting finally in brain atrophy in later stages of $\mathrm{AD}$ (Duncan and Valenzuela 2017), (Fig. 2).

Current medications for $\mathrm{AD}$ are symptomatic and are characterized by their neuromodulatory functions such as acetylcholinesterase (AChE) inhibitors (Coyle and Kershaw 2001), antioxidants (Zandi et al. 2004), and amyloid- $\beta$

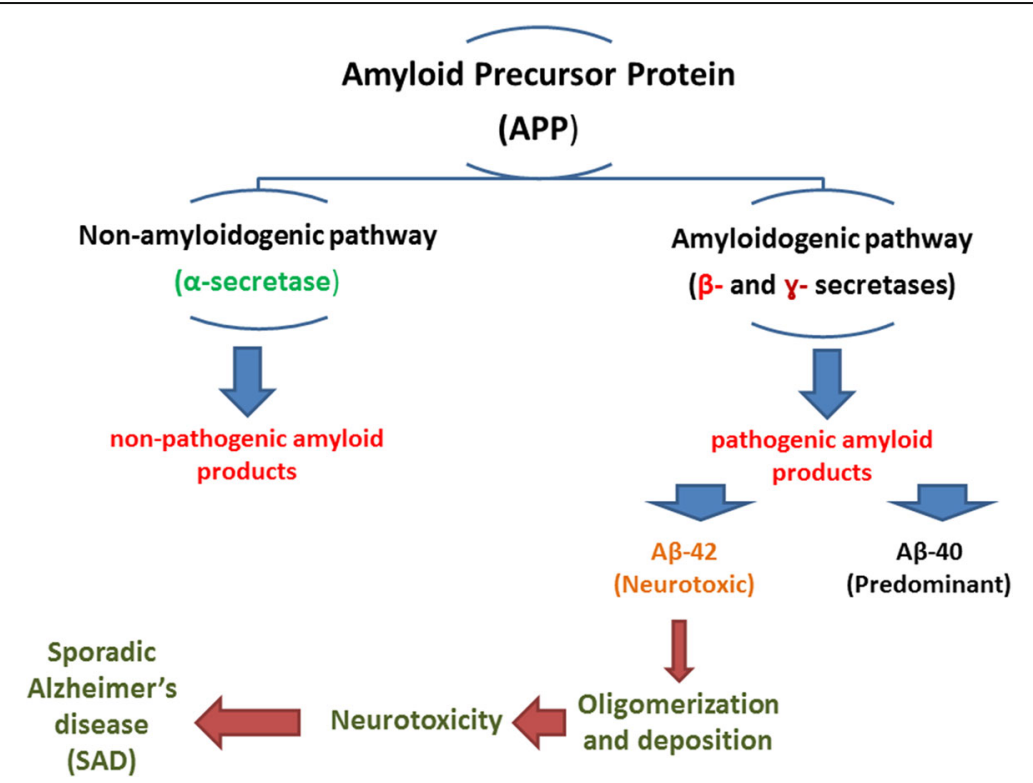

Fig. 1 The amyloidogenic and non-amyloidogenic pathways of the amyloid precursor protein (APP): APP is enzymaticaly hydrolyzed by either aor $\beta$-secretase. The non-amyloidogenic pathway, implicating a-secretase, leads to the extracellular release of non-pathogenic products. The amyloidogenic pathway, involving $\beta$-secretase (BACE1) and $\gamma$-secretase, results in the generation of amyloid products of varying length (A -40 and $A \beta-42$ ), accumulation of these neurotoxic proteins could lead to neurodegenration and might be the main cause of AD 


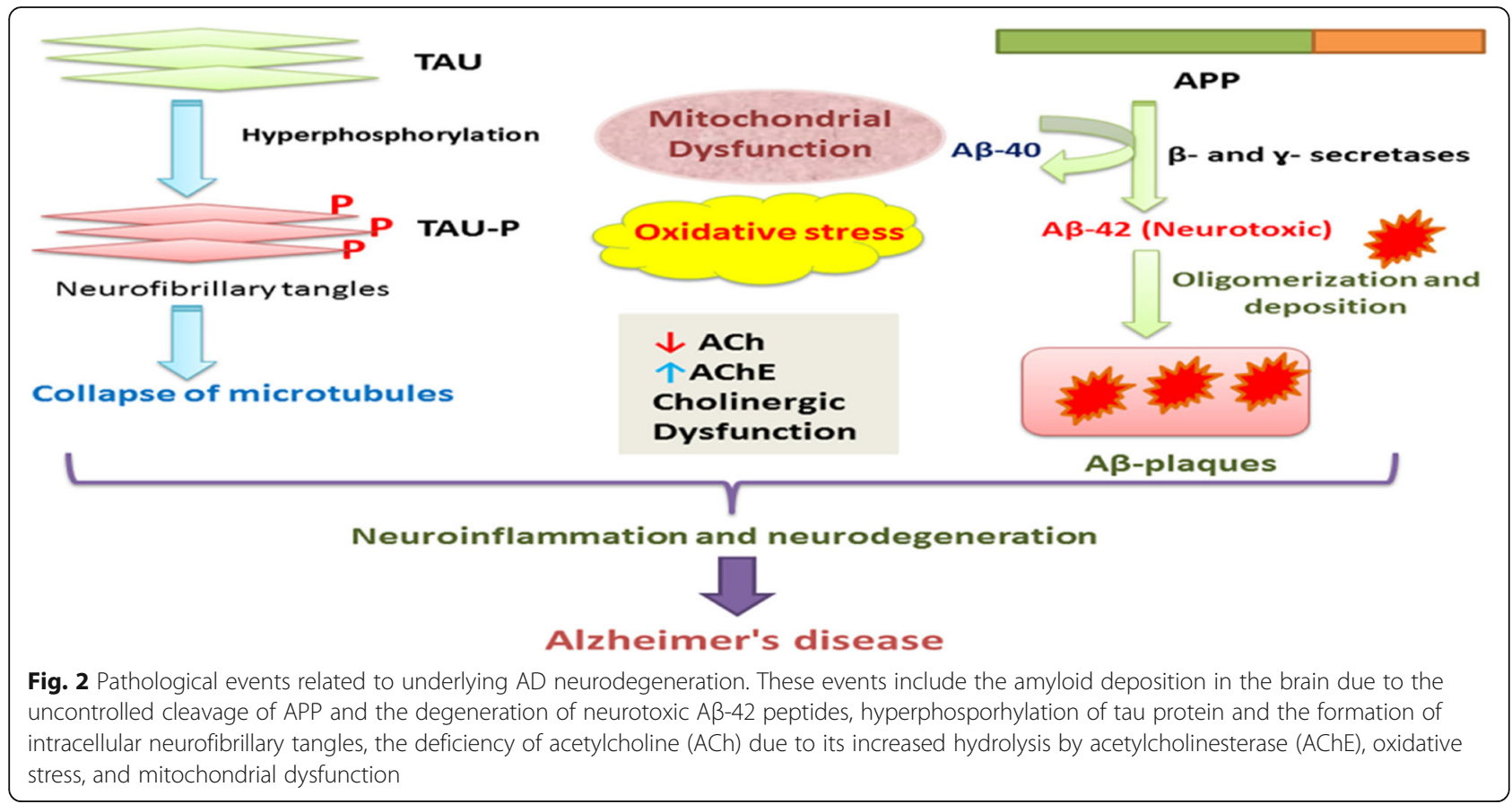

targeting medications (Cummings et al. 2017). For example, AChE inhibitors can ameliorate cholinergic function through blocking neurotransmitter degradation and increasing the brain content of neurotransmitters (Confaloni et al. 2016; Stella et al. 2015). However, this type of treatment can only provide temporary symptomatic relief without attenuating AD progression (Monacelli and Rosa 2014). Another type of treatment, such as anti-A $\beta$ aggregation agents and $\beta$-secretase inhibitors, is aimed to prevent amyloid plaque formation and to facilitate amyloid clearance (Huang and Mucke 2012; Salloway et al. 2014). However, several A $\beta$-targeting treatments failed to restore neurocognitive function (Coric et al. 2012; Doody et al. 2013; Kile et al. 2017). Actually, the "one alteration, one disease, one drug" strategy is not applied for AD (Kimura, 2016); therefore, different targets in the brain should be considered (Fang et al. 2018). Moreover, therapeutic interventions should be introduced at the early AD stages (Tong et al. 2015). Hence, it is very important to understand the etiology of AD for clinical application of alternative therapeutic approaches such as stem cell-based therapy (Banik et al. 2015).

\section{Stem cell-based therapy for AD}

Stem cell-based therapy is a promising, safe, and effective therapeutic strategy for several neurodegenerative diseases, including AD (Kocaoglu et al. 2014; Chang et al. 2014; Wernig et al. 2008). Stem cellbased-approach is still under development but rapid achievements indicate its therapeutic potential for reversing $\mathrm{AD}$-associated neurodegeneration, as well as, improving cellular and structural functions (Lee et al. 2015; Kwak et al. 2018). This therapeutic potential might be partly attributed to the neurosecretory (paracrine) effect, as several neurotrophic factors are implicated in neuromodulation of various cellular functions that ameliorate the pathological features and neurocognition in $\mathrm{AD}$ animal models (Fang et al. 2018).

Stem cells are capable of spontaneous self-renewal and subsequent differentiation into specialized cells, such as neurons and glial cells (Eriksson et al. 1998; Paspala et al. 2009). Based on the differentiation capacity, there are three types of stem cells: totipotent cells that have the potential to create an organism, pluripotent cells that can be transformed into all cell types, and multipotent cells that can be differentiated into cell types in their own tissues (Yoo et al. 2013). Based on origin, stem cells are divided into embryonic, fetal, and adult types (Takahashi et al. 2008). Choosing the suitable cell source is an important step to develop a stem cell-based therapy (Duncan and Valenzuela 2017). The most commonly utilized stem cells in AD-related studies are embryonic stem cells (ESCs), induced pluripotent stem cells (iPSCs) (Takahashi et al. 2006), mesenchymal stem cells (MSCs) (Drela et al. 2013), and neural stem cells (NSCs) (Kim et al. 2013). This review attempts to provide a simplified idea of stem cell-based therapy for AD. We described the underlying pathology of $\mathrm{AD}$ and demonstrated the different stem cells used in AD animal models and referred to their possible mechanistic actions as summarized in Table 1. 
Table 1 Transplantation studies of stem cells in AD animal models

\begin{tabular}{|c|c|c|c|}
\hline Stem cell type & AD subject & Therapeutic outcome and mechanism of action & References \\
\hline NSCs & Aged Tg-AD mice & $\begin{array}{l}\text {-Improved cognition } \\
\text {-paracrine support (BDNF) }\end{array}$ & $\begin{array}{l}\text { Blurton-Jones et al. } \\
2009\end{array}$ \\
\hline NSCs & $A D$ rats & Improved learning and memory function & Xuan et al. 2009 \\
\hline NSCS & APP /PS1 Tg mice & $\begin{array}{l}\text {-Enhanced expression of synaptic proteins } \\
\text {-Improved spatial memory }\end{array}$ & Zhang et al. 2014 \\
\hline NSCs & APP/PS1 Tg mice & $\begin{array}{l}\text {-Ameliorated cognitive deficits } \\
\text {-Anti-inflammatory activity } \\
\text { * No difference was found in A levels }\end{array}$ & Zhang et al. 2015a \\
\hline NSCs & APP /PS1 Tg mice & $\begin{array}{l}\text {-Enhanced mitochondrial biogenesis } \\
\text {-Reduced cognitive deficits }\end{array}$ & Zhang et al. 2015b \\
\hline overexpressing ChAT-NSCs & Cognitive decline-rat model & Restored cognition & Park et al. 2012 \\
\hline overexpressing ChAT-NSCS & Aged mice & Improved memory function & Park et al. 2013 \\
\hline Human NSCs & $\operatorname{Tg} 2576$ mice & $\begin{array}{l}\text {-Enhanced neurogenesis } \\
\text {-Improved cognition }\end{array}$ & Lilja et al. 2015 \\
\hline Human NSCs & $\begin{array}{l}-3 \times T g-A D \text { mice }-C a M / T e t-D T(A) \\
\text { model of neuronal loss }\end{array}$ & $\begin{array}{l}\text {-Improved cognition } \\
\text {-Enhanced synaptogenesis }\end{array}$ & Ager et al. 2015 \\
\hline NEP-expressing NSCs & $\begin{array}{l}\text {-3xTg-AD } \\
\text {-Thy1-APP mice }\end{array}$ & Anti-amyloidogenic effect & $\begin{array}{l}\text { Blurton-Jones et al. } \\
2014\end{array}$ \\
\hline MSCs & $A \beta$-treated mice & Modulated Wnt signaling pathway & Oh et al. 2015 \\
\hline UCB-MSCS & APP /PS1 Tg mice & $\begin{array}{l}\text {-Rescued memory deficits } \\
\text {-Anti-amyloidogenic effect } \\
\text {-Paracrine support }\end{array}$ & Yang et al. 2013 \\
\hline UCB-MSCS & AD model & $\begin{array}{l}\text { promoted hippocampal neurogenesis } \\
\text { and synaptic activity }\end{array}$ & Kim et al. 2015 \\
\hline UCB-MSCS & APP/PS1 Tg mice & Anti-amyloidogenic effect via SCAM-1 & Kim et al. 2012 \\
\hline Human UCB-MSC & APP/PS1Tg mice & $\begin{array}{l}\text {-Improved memory function } \\
\text {-Anti-amyloidogenic effect } \\
\text {-Anti-hyperphosphorylation of tau }\end{array}$ & Lee et al. 2012b \\
\hline adipose-derived MSCs & AD mice & $\begin{array}{l}\text { - Microglial activation } \\
\text {-Ameliorated neuropathological deficits }\end{array}$ & Ma et al. 2013 \\
\hline AT-MSCS & APP/PS1 Tg mice & $\begin{array}{l}\text {-Enhanced neurogenic activity } \\
\text {-Improved cognitive impairment }\end{array}$ & Yan et al. 2014 \\
\hline VEGF overexpressing BM-MSCs & 2xTg-AD mice & $\begin{array}{l}\text {-Anti-amyloidogenic effect } \\
\text {-Improved cognitive impairment }\end{array}$ & Garcia et al. 2014 \\
\hline BM-MSCs & $A \beta$ mice & $\begin{array}{l}\text {-Induced microglial migration when exposed } \\
\text { to } A \beta \text { in vitro } \\
\text {-Increased release of CCL5, NEP, IL-4 } \\
\text {-Anti-amyloidogenic effect } \\
\text {-Improved cognitive impairment }\end{array}$ & Lee et al. 2012a \\
\hline BM-MSCS & APP/PS1 Tg mice & $\begin{array}{l}\text {-Anti-amyloidogenic activity } \\
\text {-Anti-inflammatory effect } \\
\text {-Anti- hyperphosphorylation of tau } \\
\text {-Improved cognitive function }\end{array}$ & Lee et al. 2010 \\
\hline BM-MSCS & Aß-injected C57BL/6 mice & $\begin{array}{l}\text {-Microglial activation } \\
\text {-Anti-amyloidogenic activity }\end{array}$ & Lee et al. 2009 \\
\hline PD-MSC & $A \beta$ mouse model & $\begin{array}{l}\text {-Regulated neurogenesis, glial cell activation } \\
\text { and altering cytokine expression }\end{array}$ & Yun et al. 2013 \\
\hline MSCs & AD models & $\begin{array}{l}\text {-Enhanced autophagy } \\
\text {-Anti-amyloidogenic activity } \\
\text {-Upregulated BECN1/Beclin } 1 \text { expression }\end{array}$ & Shin et al. 2014 \\
\hline Encapsulated human -MSCs & Double Tg-AD mouse & $\begin{array}{l}\text {-Anti-amyloidogenic activity } \\
\text {-Anti-inflammatory activity }\end{array}$ & Klinge et al. 2011 \\
\hline hESC & Radiation-induced cognitive impairment & -Improved cognitive function & Acharya et al. 2009 \\
\hline ESC-derived NPCS & $A \beta$ rats & Improved cognitive function & Tang et al. 2008 \\
\hline
\end{tabular}


Table 1 Transplantation studies of stem cells in AD animal models (Continued)

\begin{tabular}{llll}
\hline Stem cell type & AD subject & Therapeutic outcome and mechanism of action & References \\
\hline ESC-derived NPCS & AD rats & Improved cognitive function & Moghadam et al. 2009 \\
iPSC-derived NPCS & APP-Tg mice & -Cholinergic function & Fujiwara et al. 2013 \\
& & -Improved spatial memory & Takamatsu et al. 2014 \\
\hline
\end{tabular}

Abbreviations: $A \beta$ amyloid beta, $A D$ Alzheimer's disease, $T g$ transgenic, APP/PS1: Tg mice amyloid precursor protein (APP)/PS1 transgenic (Tg) mice, ChAT choline acetyltransferase, UCB-MSCS umbilical cord-derived MSCs, AT-MSCs adipose tissue-derived mesenchymal stem cells, BM-MSCs bone marrow-derived MSCs, NEP neprilysin, PD-MSC placenta-derived MSCs, hESC human embryonic stem cells, NPCs neuronal precursor cells, IPSC-ML/NEP2 iPSC-derived macrophages expressing Neprilysin-2, 2xTg-AD mice double transgenic mice model of AD express APP and PS1 mutation, 3xTg-AD mice triple transgenic mice model of AD express APP PS1 and microtubule-associated protein tau (MAPT) mutation, 5XFAD mice overexpress 3 APP mutations and 2 PS1 mutations

\section{Stem cells used for the treatment of AD Neural stem cells (NSCs)}

NSCs are derived from the embryonic or adult brain and are responsible for the generation of all neural cell types such as neurons, astrocytes, and oligodendrocytes (Kim et al. 2013; Shroff 2018); their presence is restricted to neurogenic niches of the subventricular zone (SVZ) and the granular layer of the hippocampal dentate gyrus (DG) (Duncan and Valenzuela 2017). Multipotent NSCs are capable of self-renewal and differentiation into functional glia, neurons, astrocytes, and oligodendrocytes (Gage 2002) and can be obtained from fetal and postmortem neonatal brain tissues (Martínez-Morales et al. 2013) or differentiated from iPSCs and ESCs (Hermann and Storch 2013; Yu et al. 2013a, 2013b).

The mechanistic action of NSCs is regulated by metabolic processes such as oxygen consumption and energy production (Almeida and Vieira 2017; Fatt et al. 2015; Wang et al. 2012a). Mitochondrial dysfunction is implicated in AD progression (Swerdlow et al. 2014); therefore, more research is required to estimate the connection between the metabolic switch of NSCs and AD pathogenesis (Fang et al. 2018).

Experimentally, it was found that engrafted NSCs could survive, migrate, proliferate, and differentiate into cholinergic neurons, astrocytes, and oligodendrocytes, resulting in increased synaptic strength and amelioration of cognitive function in AD animal models (Yamasaki et al. 2007; Xuan et al. 2009; Blurton-Jones et al. 2009). Most NSC transplantation studies successfully recovered cognitive dysfunction in $\mathrm{AD}$ animal models but failed to decrease A $\beta$ plaques (Blurton-Jones et al. 2009; Zhang et al. 2015a; Ager et al. 2015). In another study, Park et al. (2012) demonstrated that transplantation of human choline acetyltransferase (ChAT)-NSCs into (AF64A-cholinotoxin-induced) AD rats improved cholinergic neuronal integrity through elevating $\mathrm{ACh}$ in cerebrospinal fluid (CSF). In addition, NSCs might exert "paracrine neuroprotection" through enhancing the expression and release of neurotrophic factors such as brain neurotrophic factor (BDNF) and nerve growth factor (NGF), increasing neurogenesis, and finally improving neurocognitive function in
$\mathrm{AD}$ rat model and aged primate (Blurton-Jones et al. 2009; Chen and Blurton-Jones 2012; Park et al. 2013; Fan et al. 2014). Moreover, transplanting NSCs, derived from the hippocampus of neonatal rats, into $A D$ rats resulted in the generation of new cholinergic neurons and improvement of cognitive function (Xuan et al. 2009).

Interestingly, the transplantation of human NGFexpressing NSCs (genetically modified) ameliorated cognitive function in AD mice (Lee et al. 2012a). In addition, transplantation of BDNF-overexpressing NSCs improved synaptic density and restored memory formation (Wu et al. 2016). On the other side, transplantation of genetically modified NSCs that express neprilysin (NEP), the $A \beta$-degrading enzyme, into the hippocampi of $\mathrm{AD}$ transgenic $(\mathrm{Tg})$ mice, reduced $\mathrm{A} \beta$ pathology and improved synaptic plasticity and function (Blurton-Jones et al. 2014). In accordance, transplantation of fetal NSCs into the cerebral lateral ventricles of $\mathrm{AD}$ mice resulted in activation of Akt/GSK3 $\beta$ pathway, the subsequent inhibition of tau hyperphosphorylation, and the final improvement of memory function (Lee et al. 2015). Therefore, NSC transplantation attenuated both tau- and $A \beta$ neuropathy and could represent an effective treatment against $\mathrm{AD}$ proteinopathy.

Altogether, transplanted NSCs mitigate neuroinflammation, enhance neurogenesis, promote synaptogenesis, and rescue cognitive functions of $\mathrm{AD}$ animal models (Yang et al. 2016; Lilja et al. 2015; Ager et al. 2015; Zhang et al. 2015b). Moreover, NSC transplantation resulted in modulation of cross talk between NSCs and endothelial cells (Li et al. 2006). Thus, NSC-based therapy for AD could provide a suitable neural microenvironment to inhibit neurodegeneration and to sustain the survival of mature neurons (Xuan et al. 2009). However, they are limitations to NSCs such as failure to improve $A \beta$ pathology, limited differentiation capacities to generate sufficient numbers of NSCs and cholinergic neurons, unwanted generation of non-neuronal cell types, and uncontrolled differentiation into glial cell types (Xuan et al. 2009; Ager et al. 2015; Lee et al. 2016). Moreover, NSC content in the human brain declined with age (Manganas et al. 2007). This age-associated decline in NSCs might affect the efficacy of transplantation. 
NSCs showed relatively low risks in tumorigenesis and immunogenicity; that renders them the ideal candidates for neuronal transplantation in the human brain (Kim et al. 2013). As an alternative strategy for neuronal replacement, NSCs could represent a promising and safe approach to deliver potential therapeutic agents and disease-modulating proteins (Liu 2013, Martínez-Morales et al. 2013, Chen and Blurton-Jones 2012, Dunnett and Rosser 2014; Blurton-Jones et al. 2014).

\section{Mesenchymal stem cells (MSCs)}

MSCs can be derived from various origins as demonstrated in (Fig. 3). MSCs, under certain conditions, can differentiate into different cell types of mesodermal origin such as chondrocytes, cardiomyocytes, adipocytes, osteoblasts, myocytes, and tendon cells. Interestingly, MSCs are featured by their regenerative potential due to self-renewal capacity and multipotency (Hsun and Yang 2018).

MSCs are multipotent progenitors derived from different adult tissues and are capable of in vitro self-renewal (Lanza and Atala 2014). Moreover, MSCs are capable of supporting hematopoiesis and cartilage regeneration (Bianco et al. 2013). MSCs have several modulatory features such as accessibility, ease of handling, availability, and a broad range of differentiating potential (Divya et al. 2012). MSCs are characterized by the Blood-Brain Barrier (BBB)-crossing ability, active homing ability, and efficient migratory capacity toward damaged brain regions; moreover, MSCs could be clinically used in AD patients, because of their less-invasive systemic administration (intravenously), without inducing tumorigenicity or immunogenicity, besides lacking ethical concerns (Oh et al. 2015, Ra et al. 2011, Fang et al. 2018).

MSC transplantation into AD models demonstrated neuroprotective potential through modulating neuroinflammation, boosting survival signaling, enhancing endogenous hippocampal neurogenesis, suppressing neuroapoptosis, and augmenting the Wnt signaling pathway (Oh et al. 2015; Heppner et al. 2015; Laroni et al. 2015). For instance, transplantation of Bone marrowderived MSCs (BM-MSCs) into murine AD models attenuates neuroinflammation, improves both neuropathology and neurocognitive functions (Huang and Mucke 2012). Moreover, transplantation of BM-MSCs into APP/PS1 Tg mice reduced the size of $\mathrm{pE3}-\mathrm{A} \beta$ plaque (Naaldijk et al. 2017). BM-MSCs demonstrated their ability to upregulate expression of "Nestin and ChAT-positive cells" and decreased hippocampal $\mathrm{A} \beta$ plaques at the damaged brain region (Bali et al. 2017). Furthermore, placenta-derived MSCs (PD-MSC) improved memory dysfunction in A 3 -42-infused AD mice (Yun et al. 2013).

MSCs can induce hippocampal neurogenesis through secretion of neurotrophic factors (Tfilin et al. 2010). The neuronal replacement potential of MSCs is mediated by the released neurotrophic factors (Oh et al. 2015; Teixeira et al. 2015). Transplantation of BM-MSCs into the lateral ventricles of the brain in $\mathrm{Tg} \mathrm{AD}$ mouse model increased expression of vascular endothelial growth factor (VEGF) that improved the endothelial dysfunction and enhanced synaptic plasticity (Garcia et al. 2014) and could be employed as a therapeutic approach for $\mathrm{AD}$. In addition, MSCs demonstrated anti-inflammatory and immunomodulatory activities, such as upregulating neuroprotective mediators, downregulating pro-inflammatory cytokines, and, activating microglial activity to improve A $\beta$ pathology (Lee et al. 2012a; Yang et al. 2013). These mechanistic actions exerted by MSC could render them as possible candidates for effective neuronal replacement.

In the CNS, there are two opposite microglial phenotypes: M1 (pro-inflammatory) and M2 (anti-inflammatory). M1 microglia release pro-inflammatory cytokines such as IL-1 3 . M2 microglia are induced by IL-4, IL-13, apoptotic

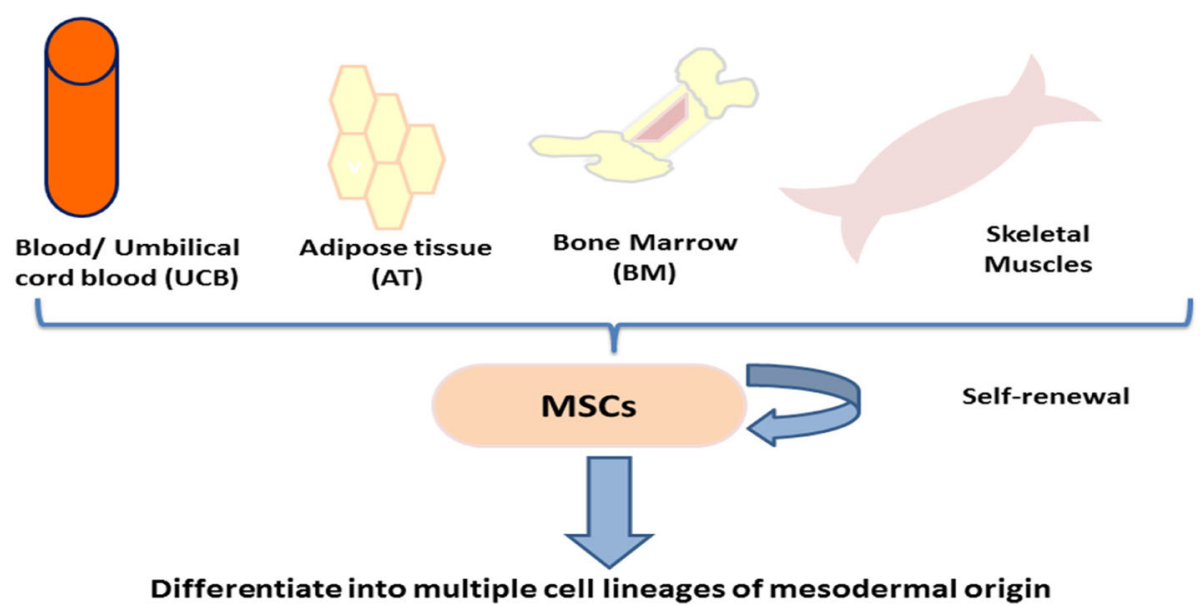

Fig. 3 Origin of mesenchymal stem cells (MSCs). MSCs can be isolated from the umbilical cord blood, bone marrow, and adipose tissue. MSCs are capable of self-renewal and differentiation into multiple cell lineages 
cells, or other anti-inflammatory cytokines (Tang and Le 2016). $M 2$ microglia are involved in ameliorating $A \beta$ neuropathy after transplantation (Ma et al. 2013; Yang et al. 2013). Therefore, targeting the balance of M1/M2 microglia and activation of M2-like microglia is a potential strategy to ameliorate AD-associated neuroinflammation (Lee et al. 2012b; Darlington et al. 2013). The anti-inflammatory and anti-amyloidogenic activities of MSCs might be attributed to microglial activation (M2 microglia) and their ability to express CCL5, a chemoattractive factor secreted by transplanted BM-MSCs, to enroll additional microglial cells (Lee et al. 2009; Lee et al. 2012b; Turgeman 2015). Bi-lateral transplantation of human umbilical cord-derived MSCs (hUCB-MSCs) into double transgenic mice released soluble intracellular adhesion molecule-1 (sICAM-1), enhanced microglial expression of $A \beta$-degrading enzymes via the sICAM-1/LFA-1 signaling pathway, and subsequently decreased hippocampal $A \beta$ plaques (González and Pacheco 2014, Kim et al. 2012), through microglial activation (Giunti et al. 2012). This proves the multi-targeting therapeutic potential of MSCs, and the activation of cell plasticity in AD brain, especially when coupled with therapeutic substances such as NEP (Laroni et al. 2015; Kim et al. 2012).

Furthermore, transplantation of BM-MSCs and UCBMSCs into $\mathrm{AD}$ animal models was able to activate endogenous microglia, to suppress monocyte-derived dendritic cells, to generate cholinergic neurons, and to decrease $A \beta$ plaques and safely recover cognitive function (Sun et al. 2013; Zhang et al. 2012). In addition, human MSCs are capable of promoting autophagy, enhancing $A \beta$ clearance, and boosting neuronal survival in $A \beta$-induced AD mice (Shin et al. 2014).

Moreover, adipose tissue-derived MSCs (AT-MSCs) might have a common transcriptional profile with BMMSCs (Peroni et al. 2008). AT-MSCs secrete neurotrophic factors and differentiate into neuron-like and astrocyte-like cells (Gutiérrez-Fernández et al. 2013; Ikegame et al. 2011). Intracerebral transplantation of AT-MSCs into APP/PS1 Tg $\mathrm{AD}$ mice enhances neurogenesis (Yan et al. 2014). In addition, AT-MSCs, when co-cultured with A $\beta$, secrete active NEP-containing exosomes (Katsuda et al. 2013b). Exosomes are cell-derived membrane vesicles that regulate physiological or pathological pathways through acting as mediators of cell-to-cell communication and transferring genetic information to recipient cells (Record et al. 2011). Furthermore, administration of exosomes could represent an alternative therapy for AD (Fang et al. 2018; El Andaloussi et al. 2013). Intravenous administration of MSC-derived exosomes enhances functional recovery in stroke-induced rats (Bang et al. 2016); this might be attributed to "miR delivery to target cells," thereby regulating the expression of genetic information and promoting a therapeutic response (Juranek et al. 2013). For instance,
MSC transplantation raised miR-133b expression in the brains of stroke-induced rats and regulated neurite outgrowth (Xin et al. 2012).

Recently, three-dimensional (3D) modeling aimed to simulate the in vivo-like microenvironment of the stem cells, to preserve their characteristics and to enhance their mechanism of action (Sart et al. 2014; Frith et al. 2010); this approach could assist the clinical application of stem cells (Bang et al. 2016). For example, "3D MSCs" expresses higher neuromodulating factors (Frith et al. 2010); thereby this type of MSCs could present a higher therapeutic potential.

Finally, we could consider that MSCs, a double-edged weapon in neurodegenerative disorders, provide both neuroprotection and immunomodulation, and at the same time, MSCs have an uncontrolled homing mechanism to lesion sites in aged AD models due to their low efficacy (Laroni et al. 2015; Fabian et al. 2017). Therefore, more research is required to understand the homing mechanism of MSCs to optimize their migration capacities and to promote the therapeutic potential of transplanted MSCs that home directly to the brain (Fang et al. 2018; De Becker and Riet 2016).

\section{Embryonic stem cells (ESCs)}

Pluripotent ESCs are stem cells derived from the inner cell mass of developing blastocysts and give rise to all cell types during the embryonic development (Lerou 2011). ESC transplantation resulted in a safe recovery of neurocognitive function in rodent models of brain injury (Acharya et al. 2009). However, because of their pluripotent differentiation capacity, ESCs demonstrated drawbacks such as the risk of tumorigenesis and uncontrolled cell growth, besides the risk of immunogenic rejection (Acharya et al. 2009; Fong et al. 2010; Ratajczak et al. 2014; Chen et al. 2015).

Nonetheless, it was suggested that ESC-derived NSCs could be safely transplanted without the risk of tumor formation (Araki et al. 2013, Tang et al. 2008). In vitro pre-differentiation of ESCs into NSCs and their subsequent transplantation into an $\mathrm{AD}$ rodent model resulted in the generation of cholinergic neurons and memory enhancement (Moghadam et al. 2009).

The conversion of ESCs into medial ganglionic eminence-like progenitor cells, and their subsequent transplantation into a murine brain injury model, resulted in amelioration of neurocognitive function through generating cholinergic and dopaminergic neuronal subtypes (Liu 2013). Transplantation of ESC-derived neural progenitor cells (NPCs) into AD animal models can result in a therapeutic outcome, through differentiation into astrocytic and neuron-like cells and enhancing memory performance (Tang et al. 2008). In addition, transplanting 
"neuron-like cell (NLC)-derived mouse ESCs (mESCs)" into AD-induced rats enhanced the neuronal connectivity and reduced brain lesions (Hoveizi et al. 2018).

They are several successful trials to differentiate ESCs into different neural cell types, including dopaminergic neurons (Krencik et al. 2011, Kriks et al. 2011, Lee et al. 2007). Human ESCs (hESCs) were able to generate astroglial cells, spinal motor neurons, and dopaminergic neurons (Lee et al. 2007). In addition, an ex vivo slice culture study reported stable functional integration of cholinergic neuron from hESCs (Bissonnette et al. 2011). However, hESCs in FDA-approved clinical trials elicit ethical concerns (Liras 2010).

The neurocognitive decline in $\mathrm{AD}$ patients may occur because of degeneration of basal forebrain cholinergic neurons (BFCNs) and the subsequent cholinergic dysfunction. Yue and Jing (2015) successfully differentiated both mouse and human ESCs into BFCNs from a highly pure population of $\mathrm{BFCN}$ progenitors. Both mouse and human ESC-derived BFCN progenitors were transplanted into transgenic $\mathrm{AD}$ mice and gave rise to functional cholinergic neurons that resulted in neurocognitive recovery. Therefore, BFCNs might be a typical model of donor cells; however, more research is required to elucidate the potential of transplanted BFCNs.

\section{Induced pluripotent stem cells (iPSCs)}

IPSCs are pluripotent stem cells reprogrammed (in vitro) from adult somatic cells (Ye et al. 2013). Takahashi et al. (2006) discovered that four transcription factors (TFs) [Sox2, Oct4, Klf4, and c-myc] could reprogram murine fibroblasts, through retroviral transduction, to ESC-pluripotency state.
iPSCs are more available, easily generated, less immunogenic, and less ethically controversial. Furthermore, iPSCs have the capacity to provide an unlimited source for different cell types. Additionally, iPSCs are regarded as "disease modeling" approach for drug screening and testing, identifying novel drugs, and patient-tailored (personalized) cell therapy (Tang 2012; Araki et al. 2013), (Fig. 4). iPSC-derived neurons are structurally and functionally mature and can form active synaptic circuits (Pang et al. 2011).

Moreover, applications of iPSCs in AD have been more concerned with the development of cell-based $\mathrm{AD}$ models (Kwak et al. 2018). Actually, using iPSC-derived neurons to recap $A D$ pathogenesis in vitro has significant applications in screening for potential therapeutic drugs (Pen and Jensen 2017). The first AD model using iPSCs was generated using five transcription factors (OCT4, SOX2, KLF4, LIN28, and NANOG) from fibroblasts of FAD patients; these iPSCs were then differentiated into neurons that may increase $A \beta-42$ expression to mimic $A \beta$ pathology; thus, these iPSCs could represent a potential strategy for the development of therapeutic drugs against AD (Yagi et al. 2011). For example, the intra-hippocampal transplantation of human iPSCderived cholinergic NPCs into a transgenic AD mouse model improved spatial memory performance by generating mature cholinergic neurons (Fujiwara et al. 2013). In addition, iPSCs could be used to generate NEPsecreting macrophages (Takamatsu et al. 2014).

To establish a successful iPSC-based therapeutic approach against $\mathrm{AD}$, we should consider the following factors: examining the haplobanks of human leukocyte antigen (HLA), defining standardized and optimized

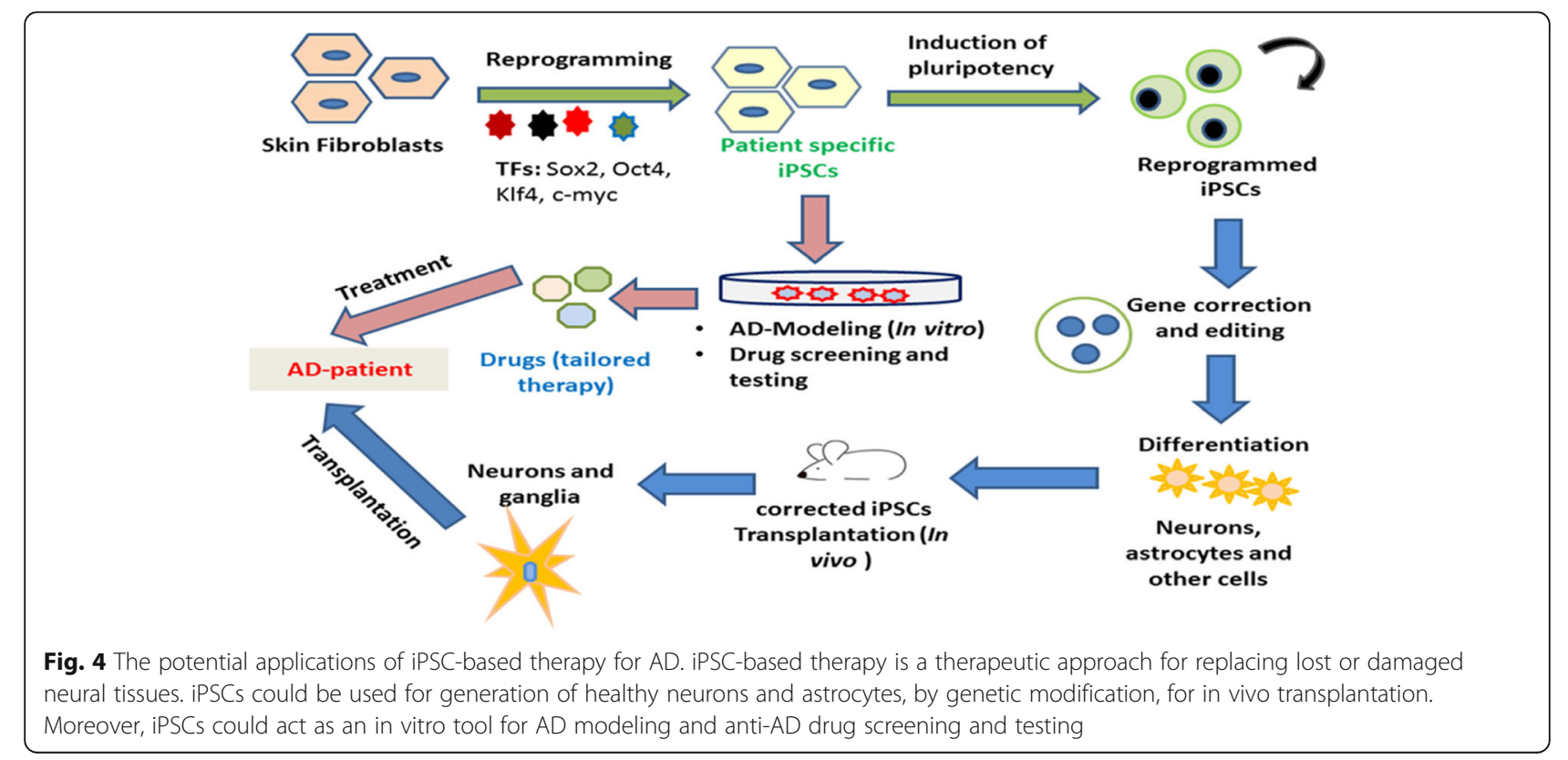


protocols to generate NSCs or hippocampal neurons, and establishing an astrocyte-generation technique for providing neurotrophic agents (Pappas et al. 2015; Hunsberger et al. 2016). Moreover, chimeric modeling and three-dimensional (3D) modeling were used to imitate different cellular interactions (such as amyloidogenic pathway) in the AD brains; in addition, genomeediting techniques were employed to enable isogenic comparison of different mutations while keeping a constant genetic background (Fang et al. 2018).

Interestingly, human iPSCs derived from somatic cells of either FAD or SAD patients contain a patient-specific (personalized) pathogenic background and can present an effective method for AD modeling, which could represent a link between preclinical (animal models) and clinical application. Moreover, it could aid in the understanding of $\mathrm{AD}$ pathogenesis, identifying therapeutic targets, and drug screening of the novel treatments against AD (Yang et al. 2016). Furthermore, it was found that human iPSC lines have only a $10-50 \%$ differentiation potential for neurons, as compared to ESCs, which have a nearly $90 \%$ differentiation potential (Wang et al. 2015), that is why, the possibility of employing iPSCs as a tool for the development of specific and tailored AD patient model systems remains challenging (Tang 2012). More interestingly, degeneration of basal forebrain cholinergic neurons (BFCNs) is closely associated with a neurocognitive decline in AD. Thus, the generation of tailored BFCNs from $\mathrm{AD}$ patient-specific iPSCs is crucial for in vitro disease modeling and for the development of novel $\mathrm{AD}$ treatments (Yang et al. 2016). BFCNs derived from SAD-iPSCs showed a significant elevation in $A \beta$ plaque formation which is regarded as a typical AD (Duan et al. 2014). Recently, Schöndorf et al. (2018) derived iPSCs from dermal fibroblasts of two SAD patients and three controls to examine SAD pathogenesis. In addition, Najar et al. (2018) generated iPSCs from two FAD patients. Thus, these studies might contribute to explain the etiology of $\mathrm{AD}$ and to influence the future treatment of AD. Therefore, iPSCs could provide unique platforms to detect the early-AD phenotypes that may help to uncover the underlying mechanisms of this neuropathy (Yang et al. 2016).

However, there are several hurdles concerning the clinical application of iPSCs such as long-term safety and efficacy, tumorigenicity, immunogenicity, patientderived genetic defects, optimal reprogramming, and ethical issues (Kwak et al. 2018; Lomax et al. 2013). For instance, using integrating (e.g., viral) vectors to generate patient-specific iPSCs results in genetic mutation and disruption of endogenous genes (Stadtfeld and Hochedlinger 2010). Additionally, viral delivery system (using retroviral or lentiviral vectors) is efficient and reproducible in reprogramming to induce iPSCs (Sommer et al. 2012); however, the random viral integration increases the risk of tumorigenesis (Okita et al. 2007). This can be avoided through transfection of linear DNA by poly-cistronic vectors, but this would result in lower reprogramming efficiency. Fortunately, many viral integration-free systems for iPSCs generation have been utilized, such as adenovirus, episomal vectors, and direct protein delivery (Yang et al. 2016).

In addition, several murine iPSCs conceal epigenetic abnormalities and continue to keep the epigenetic memory of their donor cells, as well as the absence of efficient targeting strategies to repair mutant alleles (Panopoulos et al. 2011). Therefore, generating highfidelity cells of known-fate is required for a longlasting effect of the transplantation and will have to be guaranteed before the clinical use of reprogrammed cells (Pen and Jensen 2017).

\section{Other cells}

Novel sources of stem cell have demonstrated potential in neuronal-regeneration, including neural crest stem cells, hematopoietic stem cells, human dental pulp stem cells (DPSCs), and olfactory ensheathing cells (Kwak et al. 2018). For example, DPSCs are being examined as a potential stem cell source for transplantation in AD models (Apel et al. 2009; Ahmed et al. 2016). DPSCs are cranial neural crest-derived MSCs that facilitate their neural differentiation (Mead et al. 2017). Moreover, DPSCs are easily harvested, available, less invasive, and less immunogenic and demonstrate neurotrophic potential (Luo et al. 2018). Notably, the somatic cell nuclear transfer procedure involving olfactory ensheathing cells, via the intranasal route, is another promising technology (Baig and Khan 2014; Baig 2014).

Remarkably, there are very few reports registered at https://www.clinicaltrials.gov/ of transplantation of stem cells in AD patients. In 2011, Medipost Co Ltd. completed an open level, phase I safety and efficacy trial on Korean AD patients, but the outcomes were not revealed (Bali et al. 2017). There has been increasing commercial interest to convert preclinical studies into clinical practice on AD patients. Actually, the growing interest in stem cell transplantation should be controlled by governmental regulations (Fang et al. 2018). Several laws and guidelines under agencies like the Food and Drug Administration (FDA), the European Medicines Agency (EMA), and others control stem cell-based therapy (Frese et al. 2016).

\section{Mechanistic actions of transplanted stem cells for treatment of $A D$}

Regenerative medicine using stem cells could represent a promising therapeutic approach for the management of chronic disorders like $\mathrm{AD}$; this is mainly attributed to the potential actions exerted by stem cells such as improving 
the neurogenic potential, exerting anti-inflammatory effect, presenting neurotrophic support, and having an anti-amyloidogenic potential (Fig. 5, Table 1).

\section{Induction of endogenous neurogenesis (neurogenic potential)}

Neurogenesis (neural regeneration) is the process of differentiation of neural progenitor cells (NPCs) into specific, functional, and fate-known new neurons, which synaptically integrated into the pre-existing neural circuit of the host (Ming and Song 2005; Jin and Galvan 2007). It takes place in the subgranular zone (SGZ) of the dentate gyrus (DG) and the subventricular zone (SVZ) of the lateral ventricles (Alvarez-Buylla and GarciaVerdugo 2002). In humans, the neurogenic potential declines normally with age and is associated with AD progression (Donovan et al. 2006; Klempin and Kempermann 2007; Lopez-Toledano and Shelanski 2007a), impaired neurogenesis plays a role in $\mathrm{AD}$ pathogenesis (Hollands et al. 2016). AD murine models demonstrated dysfunction of neurogenesis; this refers to the imbalance between neuroregeneration and neurodegeneration (Haughey et al. 2002). Neurogenesis is associated with maintenance of neurocognitive function; therefore, stimulation of adult neurogenesis has been the main target in $\mathrm{AD}$ treatment ( $\mathrm{Li}$ et al. 2015). Several effector molecules are both involved in AD pathogenesis, and, in the modulation of neurogenesis; such as apolipoprotein E (ApoE), PS1, APP, neurotrophic factors, transcription factors, metabolic factors, and epigenetic regulators (Yang et al. 2011; Gadadhar et al. 2011; Ghosal et al. 2010; Horgusluoglu et al.
2017). Therefore, neurogenesis is enhanced as a selfrepairing mechanism in the early stages of $\mathrm{AD}$; however, the survival of newly generated neurons was hampered by the progression of neurodegeneration (Chen et al. 2008). For instance, deposited $A \beta$ plaques could impair neurogenesis in AD animal model (Veeraraghavalu et al. 2010). Therefore, application of stem cell-based therapy for AD depends on the neurogenic capacities of stem cells, identifying key molecules in the modulation of endogenous neurogenesis (Zhang and Jiang 2015; Fang et al. 2018).

Transplanted stem cells can enhance endogenous neurogenesis to replace damaged neurons in the AD brain (Mu and Gage 2011; Kanno 2013). Novel neurons, derived from donor cells or activated neurogenesis, demonstrated their ability to mediate structural and functional integration in the pre-existing network and to modulate neurogenesis ( $\mathrm{Yu}$ et al. 2013a, 2013b; Bonaguidi et al. 2011). These new neurons are capable of secreting neurotrophic factors (Enciu et al. 2011) and increasing brain ACh levels, thus improving neurocognitive functions in AD animal models (Park et al. 2013; Park et al. 2012; Yang et al. 2013; Ma et al. 2013; Njie et al. 2012). Furthermore, genetically reprogrammed stem cells can possess the migratory capacity and can be employed as vehicles to deliver neurotrophic factors or to enhance genetic expression that can alter the $\mathrm{AD}$ pathway (Mucke 2009). As demonstrated in AD animal models, transplanted stem cells have the potential to improve several cellular functions, such as synaptic connectivity (Blurton-Jones et al. 2009), neurogenesis (Kim et al. 2015), microglial activity (Yang et al. 2013), angiogenesis

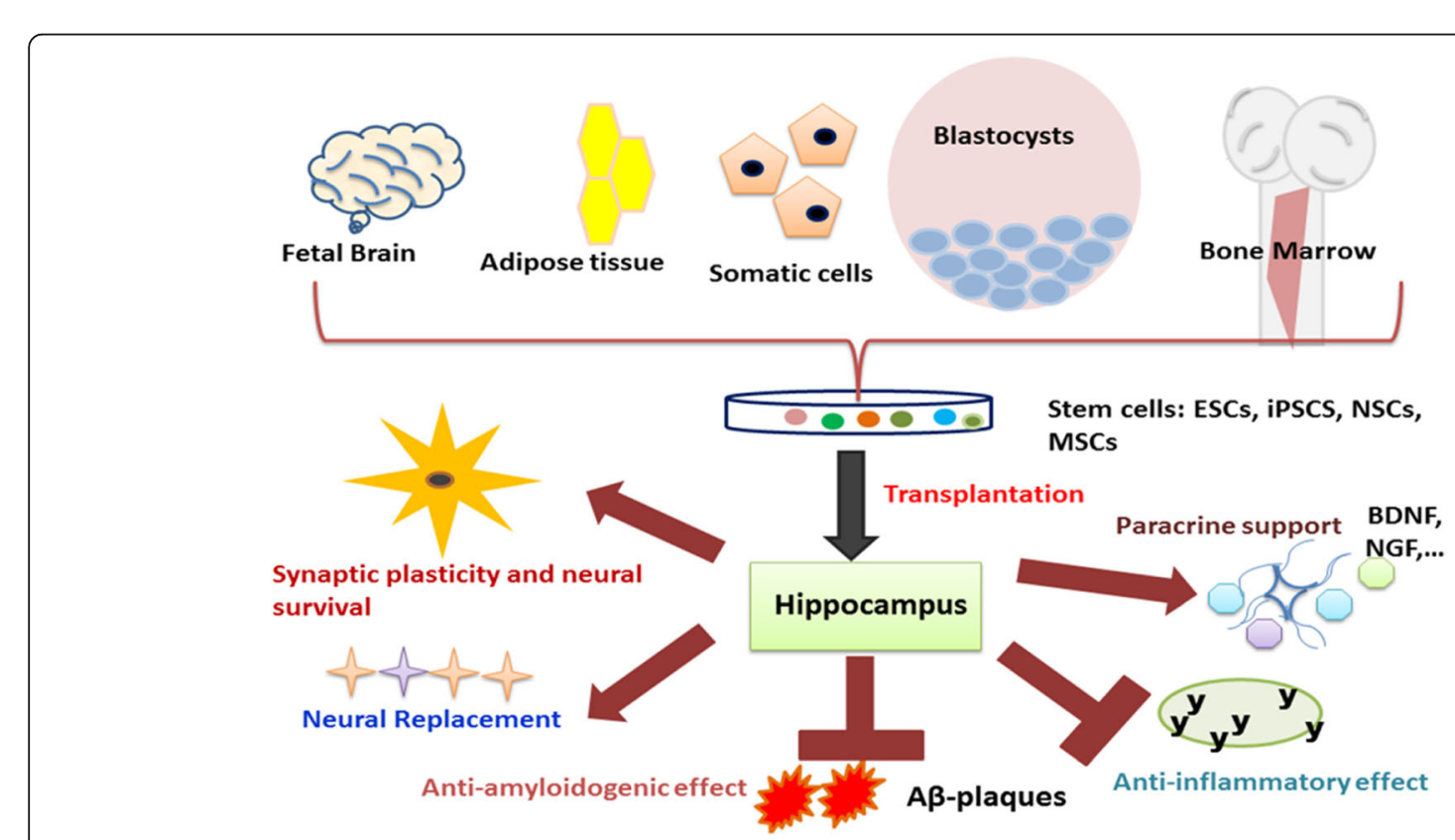

Fig. 5 The potential mechanistic actions exerted by stem cells against Alzheimer's disease 
(Garcia et al. 2014), mitochondrial function (Zhang et al. 2015b), and autophagy (Shin et al. 2014). Therefore, stem cell transplantation could represent a promising and safe approach to treat $\mathrm{AD}$, as it affects this disease through multiple mechanisms that result in re-building the neural integrity and improving the neurocognitive function (Fang et al. 2018; Lee et al. 2016; Choi et al. 2014a).

However, it has been suggested that engrafted stem cells are not the sole source of the newly generated neurons (Sullivan et al. 2015; Zhang et al. 2013). Hence, rather than using the cell-replacement model in $\mathrm{AD}$, activation of endogenous NPCs and stimulation of neurogenesis could improve the microenvironment, support neuroregeneration, and enhance the survival of injured neurons (Lunn et al. 2011), and prevent secondary neuronal damage, through the neurotrophic support (Burns et al. 2009).

\section{Neurotrophic and neuroprotective activity}

Transplanted stem cells demonstrated neurotrophic/paracrine potential (Martino and Pluchino 2006), through increasing the levels of different neurotrophic factors such as brain-derived neurotrophic factor (BDNF)-the classic paracrine mediator-(Blurton-Jones et al. 2009), glial cell line-derived neurotrophic factor (GDNF) (Kim et al. 2012), insulin-like growth factor 1 (IGF-1) (Klinge et al. 2011), glucagon-like peptide-1 (GLP-1) (Zhang et al. 2014), nerve growth factor (NGF) (Jin et al. 2002), and vascular endothelial growth factor (VEGF) (Garcia et al. 2014). For example, NSCs, ESCs, and MSCs can express high levels of BDNF and NGF, which are important positive neuroregulators in endogenous neuronal survival and synaptic plasticity (Yan et al. 2014). Moreover, Blurton-Jones et al. (2009) showed that NSC transplantation into the brains of transgenic AD models elevated brain BDNF levels and enhanced the hippocampal synaptic density. Similarly, Yan et al. (2014) demonstrated that MSC transplantation induced endogenic activity in the hippocampal SGZ and SVZ and improved cognitive function in APP/PS1 transgenic AD mice. In addition, transplantation of NGF-expressing human NSCs (hNSCs) into the hippocampi of ibotenic acid-injected mice (a model of neurocognitive dysfunction) exerted neuroregenerative potential and restored memory formation (Wang et al. 2012b). Furthermore, Chen and Blurton-Jones (2012) found that delivery of recombinant BDNF could resemble the potential of NSC transplantation in AD transgenic animals.

BDNF and CREB (cAMP response element-binding protein) play a major role in the process of memory formation and consolidation (Song et al. 2015; Dominguez et al. 2016). Since CREB is a DNA-binding protein and acts as a transcription factor for BDNF, it is possible that a relationship exists between the role of BDNF expression and its regulation by CREB in restoring memory function (Lee et al. 2013). Suzuki et al. (2011) reported that elevated BDNF levels were associated with improvement of both long-term memory (LTM) and short-term memory (STM), suggesting that CREB-mediated BDNF expression plays an intrinsic role in memory formation. Besides secreting neurotrophic factors, the therapeutic potential of stem cell-derived extracellular vesicles was also investigated (Katsuda et al. 2013a).

It is essential to upregulate (either pharmacologically or with gene therapy) the neurotrophic factors (Jin et al. 2002). Nonetheless, this is complicated by several obstacles, such as the age-dependent decline of hippocampal neurogenesis, the massive loss of hippocampal neurons in $\mathrm{AD}$ patients, and the possible effect of $\mathrm{AD}$ pathology on neurogenesis (Lopez-Toledano et al. 2007a, 2007b). Moreover, endogenous NSCs demonstrated a limited capacity to compensate for damaged cells, as well as, NSCs become "gliogenic" rather than neurogenic ( $\mathrm{Li}$ et al. 2010). Therefore, the comprehensive mechanism of endogenous neuroregeneration needs more clarification (Tang 2012).

\section{Immunomodulation and anti-inflammatory activity}

Chronic inflammation is involved in neurodegenerative diseases, including AD (Voloboueva and Giffard 2011). Certain stem cell types such as NSCs and MSCs showed antiinflammatory activities by decreasing pro-inflammatory cytokines and upregulating anti-inflammatory factors (Ylostalo et al. 2012). MSCs represent a good source of inflammatory mediators and growth factors (Caplan and Dennis 2006). Moreover, MSCs could deliver therapeutic molecules such as proteins (Hsun and Yang 2018).

UCB-MSC transplantation into transgenic AD mice attenuated neuroinflammation, induced microglial expression of neprilysin (NEP), decreased hippocampal $\mathrm{A} \beta$ plaques, and ameliorated neurocognitive function (Kim et al. 2012). Moreover, intra-hippocampal transplantation of NPCs into $A \beta-42$ peptide-injected hippocampi in $\mathrm{AD}$ rats is neuroprotective and attenuates inflammatory reactivity (Ryu et al. 2009).

Noteworthy, "Cholinergic anti-inflammatory pathway" is mediated by $\mathrm{ACh}$, which has anti-inflammatory activity, through inhibiting production of tumor necrosis factor (TNF- $\alpha$ ) and IL-1 $\beta$ and suppressing the activation of nuclear factor-kB (NF-kB) (Pavlov and Tracey 2006). Transplantation of ChAT-overexpressing human NSCs (HB1.F3.ChAT) into AD animal models restored neurocognitive function and improved memory function; this might be attributed to the elevated levels of ACh in CSF and the successful migration of transplanted cells to affected brain regions (Naert 2012; Kim et al. 2012). Therefore, cell-based 
therapies that simultaneously increase neurotransmitters and growth factors could achieve better outcomes (Choi et al. 2014a).

\section{Anti-amyloidogenic potential}

Alzheimer's disease (AD) is characterized by the deposition of neurotoxic A $\beta$ plaques (Walsh and Selkoe 2004). Therefore, stem cells transplantation is an effective and promising strategy for functional recovery for $\mathrm{AD}$ (Choi et al. 2014a), through enhancing the clearance of $A \beta$ plaques. For instance, transplanted MSCs into murine $\mathrm{AD}$ models increased NEP expression, cleared $\mathrm{A} \beta$ aggregates, and enhanced neural survival (Bales et al. 2006; Szabo et al. 2008; Choi et al. 2014a). Moreover, NSCs can express metalloproteinase 9 (MMP9) which is regarded as a degrading enzyme for A $\beta$ peptides (Miller et al. 2003). Similarly, adipose tissue-derived stem cells (ADSCs) demonstrated a similar anti-amyloidogenic potential coupled with anti-inflammatory activity (Melchor et al. 2003). Moreover, transplanting stromal cell-derived factor- 1 into $\mathrm{AD}$ transgenic animals resulted in clearance of $A \beta$ plaques (Xue et al. 2012). Additionally, engrafted MSCs cleared A $\beta$ plaques, through differentiating into microglia or recruitment of activated microglia (Lee et al. 2012a).

Autophagy plays a critical role in maintaining $A \beta$ homeostasis by enhancing the clearance of $A \beta$ deposits in the brain (Shin et al. 2014). Autophagy acts as a cytoprotective response, under stress conditions, for the degradation of abnormal and aggregated proteins (Cuervo et al. 2010). Dysfunction in the autophagic system may lead to deposition of $A \beta$ plaques (Shin et al. 2014). They are several autophagic vacuoles (AVs) that accumulate in the AD brains (Lee et al. 2010). Autophagy markers (e.g., ATG5, ATG12, and microtubule-associated protein 1 light chain 3 [LC3]) are correlated with A $\beta$ neuropathology (Ma et al. 2010). Moreover, the immunofluorescent analysis showed that MSC transplantation raised fusion of A $\beta$-containing auto-phagosomes (LC3-II) and lysosomes (LAMP2), raised activity of lysosomal enzymes, and enhanced the autolysosome formation and catabolic function, which may be accompanied with neuronal survival. This neuroprotective potential might be attributed to lysosomal activity mediated through autolysosome formation. Thus, using MSCs to modulate the autophagy mechanism might be a promising therapeutic strategy for AD (Shin et al. 2014). It was evidenced that some compounds can reduce $A \beta$ levels through activation of autophagy or lysosomal proteolysis (Parr et al. 2012; Lai and McLaurin 2012). MSC transplantation into an $\mathrm{AD}$ animal model $(\mathrm{A} \beta$ intoxicated) resulted in a marked increase in autophagosome induction and a significant decrease in $A \beta$ levels (Shin et al. 2014). This confirms the potential role of MSCs as an autophagy modulator that enhances clearance of neurotoxic $\mathrm{A} \beta$ deposits; thus, a therapeutic strategy for
$A D$ is to enhance $A \beta$ clearance through induction of the autophagy-lysosome pathway (Caplan and Dennis 2006; Shin et al. 2014).

\section{Challenges in stem cell-based therapies of $A D$}

They are several challenges concerning the clinical translation of stem cell-based therapy such as tumorigenicity, immune rejection, contamination, genetic modification, uncontrolled migration and growth, and unintended trans-differentiation (Kwak et al. 2018). Therefore, more research is required to set protocols for standard preparation of cells suitable for transplantation, to clarify the mechanism underlying symptomatic relief upon transplantation, and to determine the immune response after transplantation (Yue and Jing 2015). Furthermore, the safety and efficacy of transplanting genetically-engineered cells in humans have not yet been legitimized, as well as, there is a need for stem cell genome alteration which could encounter ethical restrictions (Fang et al. 2018). Some of those issues are listed below:

\section{Time of transplantation}

Regarding that $\mathrm{AD}$ is a progressive chronic disease that takes several years before clinical manifestation of symptoms; it is essential to determine the appropriate time window for transplantation during $\mathrm{AD}$ progression (Fang et al. 2018). It was suggested that NSC transplantation, at the onset of AD, is more effective when the brain suffers the fewest alterations in microenvironment detrimental to neurogenesis (Fan et al. 2014). Moreover, the hippocampus, in the early stage of $\mathrm{AD}$, could be the main therapeutic target (Stensola et al. 2012). For example, one study used the transgenic (Tg2576) murine model (12-month-old), demonstrated age-related neurocognitive decline, showed that transplantation restored neurocognition, and improved AD neuropathology, while transplantation failed in a 15-month-old mice (Kim et al. 2015). Therefore, the therapeutic approach will become more complicated and less effective, as the $\mathrm{AD}$ associated neurodegeneration progresses.

MSC transplantation into elder stroke-patients, who already have a limited content of NSCs/NPCs and BM-MSCs, will be of no significance because of loss of regenerative capacity of MSCs (Bang et al. 2016). This attenuation of the potential of stem cell-based therapy in aged patients could result from aging in either the donor cells or the host cells (Manganas et al. 2007). In addition, the neurogenic activity of BM-MSCs declined with age; this implies the significance of the "aging/rejuvenation of donor cells" to the efficiency of stem cell-based therapy (Bang et al. 2016). 


\section{Location of transplantation}

Determining the ideal site for introducing the new population of neurons/stem cells is of great importance and may play a critical role in the treatment of $\mathrm{AD}$. The NSC-rich regions like the hippocampus and the lateral ventricles are possible candidates (Bock et al. 2011). Therefore, the hippocampus is the typical target site for introduction of transplanted cells in $\mathrm{AD}$ patients (Igarashi et al. 2014).

The recognition of grid cells and functionally specialized neurons and the establishment of computational models of grid cells make it possible to detect the damaged neurons and affected neural circuits (Giocomo et al. 2011). However, it is still difficult to attain an accurate grid map of the brain due to its complex structure and overlapping functions in AD. Therefore, it is necessary to develop more precise brain grid charts to estimate the ideal locations for cell transplantation for each AD patient (Li et al. 2015).

\section{Donor-to-donor heterogeneity}

Identifying "genetic and epigenetic backgrounds" of donor cells is essential for successful transplantation. Although the brain is immune-privileged, the human leukocyte antigen (HLA) profile of donor cells must be examined to avoid the immune response after transplantation (Chen et al. 2012). During the production of neuronal cells for transplantation, the genetic defects responsible for $\mathrm{AD}$ symptoms must be corrected in the donor cells (Yagi et al. 2011). For instance, heterogeneity between iPSC clones from the same individual and iPSCs from different individuals is the major obstacle in the application of iPSC-technology (Arber et al. 2017); this could be achieved by genetic editing with molecular scissors such as CRISPR (Marchetto et al. 2009). Selecting pure donor cells could reduce variability and improve functional outcomes in the newly generated products (Yuan et al. 2011).

Instead of using the immunosuppressive agents (Freed et al. 1992), "cell encapsulation techniques" were used to avoid the possible immune rejection of the transplanted cells; the encapsulated cells are protected with a polymeric semi-permeable membrane, which permits the exchange of essential molecules for cellular metabolism, from the immune response for a stable delivery of therapeutic agents. For example, encapsulated somatic cells were employed to deliver trophic factors to treat AD (Garcia et al. 2010; Spuch et al. 2010; Eriksdotter-Jönhagen et al. 2012; Wahlberg et al. 2012). For example, encapsulated MSCs transfected with GLP-1 were capable of inhibiting inflammatory events (Klinge et al. 2011). Moreover, in vivo or in situ reprogramming of iPSCs might represent a solution for the possibilities of transplantation rejection and tumorigenesis (Qu et al. 2001, Zhou et al. 2008).

\section{Functional integration}

Stem cell-based therapy for AD should be accompanied by the administration of antioxidants and neurotrophic factors. NSC transplantation exerts a neurogenic potential by providing paracrine support to existing NSCs rather than forming new functional neurons (Feng et al. 2009). Additionally, the transplantation of stem cells is often accompanied by massive death of transplanted cells in the brain (Limke and Rao 2003). New strategies such as "deep brain stimulation" showed positive outcomes in relieving AD symptoms (Gratwicke et al. 2013; Hescham et al. 2013).

\section{Ethical issues and safety concerns}

Stem cell-based therapy is an ethically challenging process; it is considered an invasive procedure that could cause several clinical complications and direct harm to the already damaged areas. Ethically, it is important to estimate the efficacy of transplantationbased therapy, to decrease the risk of therapeutic misconception, to reduce the risk of pain, and to highlight the importance of informed consent (Ciervo et al. 2017; King and Perrin 2014). Actually, the debate of ethical concerns in stem cell-based therapy showed the difficult equilibrium between the imperatives of caution and the progress for clinical trials (King and Perrin 2014). Translation of preclinical studies into successful clinical trials for AD provokes several ethical and safety concerns. For instance, the unlimited and undesired differentiation capacity of iPSCs raises the risk of non-ethical generation of genetically modified human embryos, human cloning, and human-animal chimeras, as well as, the risk of tumorigenesis. Similarly, MSC transplantation provokes safety issues concerning their capacity to induce tumor growth and metastasis (Volarevic et al. 2018). The ethical issue concerning the destruction of a human embryo hindered the development of clinical application of hESC; moreover, the pluripotent nature of hESCs renders them more prone to form tumors due to their uncontrolled growth after in vivo transplantation (Nussbaum et al. 2007). Thus, iPSCs are considered morally superior to hESCs (Meyer 2008); however, the main safety challenge regarding iPSCbased therapy is the risk of teratoma formation due to the uncontrolled differentiation (Wernig et al. 2008). In addition, the difference between the niche of the host cells and that of the in vitro cultured cells reduces the proliferative and differentiating capacity (Marks et al. 2017). 
Reprogramming of somatic adult cells into NSCs could solve the problem of the immune rejection by "autologous transplantation" and evade the ethical limitations associated with the use of embryonic (fetal)derived stem cells. Besides ethical and safety concerns, the efficiency of reprogramming and the epigenetic background of stem cells are among the obstacles that should be avoided before the clinical translation of iPSCs (Ciervo et al. 2017). On the other side, MSCs can be obtained easily from patients allowing "autologous transplantation" and avoiding ethical limitations related to the use of ESCs (Lewis and Suzuki 2014).

\section{In vitro senescence of stem cells}

The incomplete success to translate preclinical studies into clinical application might be attributed to the age-related regenerative activity between $\mathrm{AD}$ animal models and AD patients (Bang et al. 2016). Stem cells such as MSCs are subjected to "in vitro senescence" which might affect their performances through losing their characteristics (e.g., homing capacity, proliferation, paracrine function) during "ex vivo culturing" (Bonab et al. 2006; Li et al. 2008). In addition, AD occurs mostly in aged patients, thus "aged" MSCs derived from aged $\mathrm{AD}$ patients showed the characteristics of senescence, such as losing the differentiation capacity.

Therefore, it is important to evade age-associated defects such as shorter telomere length in transplanted cells (Yang et al. 2018). This could take place by presenting "retroviral vectors that carry the gene for the catalytic subunit of telomerase" to MSCs and therefore guarantee the normal proliferation and differentiation capacity during "large-scale expansion" (Hsun and Yang 2018). Finally, the in vitro approach of "large-scale expansion" is aimed to generate a massive population of stem cells for clinical therapy; this is accompanied with the use of anti-aging (senolytic) drugs such as nicotinamide riboside, quercetin, and danazol (Grezella et al. 2018). In addition, transplanted stem cells should be differentiated on large-scale "in vitro," without affecting their cellular identity and genetic profile, to ensure their efficacy (Zonari et al. 2017; Marks et al. 2017).

\section{Future directions of stem cell-based therapy against $A D$}

Future research should be directed to define a standardized protocol for isolation and differentiation of stem cells, through identifying their sources and designing methodologies for their isolation and differentiation into different lineages (Avinash et al. 2017). More research is required to define the sources, types, stages, doses, and routes of stem cell transplantation in AD animal models to validate their optimum therapeutic outcome (Banik et al. 2015).
Administration of anti-oxidative nutraceuticals such as polyphenols could help to prevent AD progression (Borai et al. 2017). For example, resveratrol, a grapederived polyphenolic compound, facilitates transplantation of hUC-MSCs into the brains of AD mice and promotes functional outcomes of MSCs through activating SIRT1 signaling pathway and stimulating NPCs proliferation, and finally enhances neurocognitive function (Wang et al. 2018).

Moreover, using nanomaterials in combination with stem cells could introduce several applications in brain regenerative studies (Alipour et al. 2018). Nanomaterials provide an ideal platform for enhancing the efficacy of stem cell treatment (Misra et al. 2016), imaging and tracking of stem cells (Sibov et al. 2014), implying genetic modifications to mediate stem cell proliferation and differentiation (Tiwari et al. 2013), and improving neuronal differentiation of stem cells into neurons (Stephanopoulos et al. 2014). For example, administration of curcumin-encapsulated PLGA nanoparticles (Cur-PLGA-NPs) into $A \beta$-treated rats upregulated the genes necessary for the NSC proliferation and differentiation, activated Wnt signaling pathway, and improved neurocognitive function (Tiwari et al. 2013).

In time, more advanced stem cell therapies hold the potential for the clinical treatment of AD (Li et al. 2014). The safe and ethical future of stem cell-based therapy for $\mathrm{AD}$ will be slow, expensive, and tightly regulated (Dunnett and Rosser 2014).

\section{Conclusion}

This review has summarized the relevant use of stem cell-based therapy for the management of Alzheimer's disease (AD). Treatment of complicated $\mathrm{AD}$ requires targeting multiple pathogenic pathways; therefore, stem cell-based therapy might represent a multi-target therapeutic intervention that enhances neuroregeneration and suppresses neurodegeneration through exerting anti-inflammatory, anti-amyloidogenic, immunomodulating, and neuroprotective activities. However, more research is required to evaluate the most effective combination of therapeutic actions of stem cells to amend AD pathology, to apply supporting approaches that could improve mechanistic actions of stem cells such as genetic editing and 3D modeling and to provide supporting synergistic treatments such as administration of natural products, nanoparticles, and antioxidants. Several preclinical trials provided an optimistic prospect for treating $\mathrm{AD}$ and paved the way for the subsequent clinical application of stem cell-based therapy, which requires standardized protocols for the isolation and expansion of stem cells to get the desired therapeutic outcome. Finally, moving forward in the rapidly advanced stem cell research demands the proper combination of creativity, accuracy, and caution. 


\section{Abbreviations}

ACh: Acetylcholine; AD: Alzheimer's disease; ADSCs: Adipose tissue-derived stem cells; ApoE: Apolipoprotein E; APP: Amyloid precursor protein; A $\beta$ plaques: Amyloid- $\beta$ plaques; BDNF: Brain neurotrophic factor; BFCNs: Basal forebrain cholinergic neurons; CAMP: Cyclic adenosine monophosphate; CNS: Central nervous system; CREB: CAMP response element-binding protein; Cur-PLGA-NPs: Curcumin-encapsulated PLGA nanoparticles; DG: Dentate gyrus; DPSCs: Dental pulp stem cells; ESCs: Embryonic stem cells; GDNF: Glial cell line-derived neurotrophic factor; GLP-1: Glucagon-like peptide-1; HLA: Human leukocyte antigen; IGF-1: Insulin growth factor-1; iPSCs: Induced pluripotent stem cells; LTM: Long-term memory; MMP9: Metalloproteinase 9; MSCs: Mesenchymal stem cells; NEP: Neprilysin; NF-kB: Nuclear factor-kB; NFTs: Neurofibrillary tangles; NGF: Nerve growth factor; NPCs: Neural progenitor cells; NSCs: Neural stem cells; PS1: Presenilin 1; PS2: Presenilin 2; ROS: Reactive oxygen species; STM: Short-term memory; SVZ: Subventricular zone; TFs: Transcription factors; UCB: Umbilical cord blood; VEGF: Vascular endothelial growth factor

\section{Acknowledgements}

The author would like to acknowledge the National Research center (NRC) for supporting and facilitating this work and would like to thank reviewers for their in-depth comments that improved the manuscript.

\section{Funding}

Not applicable.

\section{Availability of data and materials}

Not applicable.

\section{Authors' contributions}

The corresponding author wrote and approved the final manuscript.

\section{Ethics approval and consent to participate}

Not applicable.

\section{Consent for publication}

Not applicable.

\section{Competing interests}

The author declares that there are no competing interests.

\section{Publisher's Note}

Springer Nature remains neutral with regard to jurisdictional claims in published maps and institutional affiliations.

\section{Received: 8 January 2019 Accepted: 19 February 2019}

Published online: 29 March 2019

\section{References}

Acharya MM, Christie LA, Lan ML, Donovan PJ, Cotman CW, Fike JR, Limoli $C L$ (2009) Rescue of radiation-induced cognitive impairment through cranial transplantation of human embryonic stem cells. Proc Natl Acad Sci 106:19150-19155

Ager RR, Davis JL, Agazaryan A, Benavente F, Poon WW, La Ferla FM, BlurtonJones M (2015) Human neural stem cells improve cognition and promote synaptic growth in two complementary transgenic models of Alzheimer's disease and neuronal loss. Hippocampus 25:813-826

Ahmed NM, Murakami M, Hirose Y, Nakashima M (2016) Therapeutic potential of dental pulp stem cell secretome for Alzheimer's disease treatment: an in vitro study. Stem Cells Int 8102478. https://doi.org/10.1155/2016/8102478

Alipour M, Nabavi SM, Arab L et al (2018) Stem cell therapy in Alzheimer's disease: possible benefits and limiting drawbacks. Mol Biol Rep. https://doi. org/10.1007/s11033-018-4499-7

Almeida AS, Vieira HLA (2017) Role of cell metabolism and mitochondrial function during adult neurogenesis. Neurochem Res 42:1787-1794

Alvarez-Buylla A, Garcia-Verdugo JM (2002) Neurogenesis in adult subventricular zone. J Neurosci 22:629-634

Alzheimer's Association, Alzheimer's Disease Facts and Figures. Alzheimer's \& Dem. 2016;12(4). https://doi.org/10.1016/j.jalz.2016.03.001

Amemori T, Jendelova P, Ruzicka J, Urdzikova LM, Sykova E. Alzheimer's Disease: Mechanism and Approach to Cell Therapy. Int J Mol Sci. 2015;16(11):26417-51.
Apel C, Forlenza OV, de Paula VJR, Talib LL, Denecke B, Eduardo CP et al (2009) The neuroprotective effect of dental pulp cells in models of Alzheimer's and Parkinson's disease. J Neural Transm 116:71-78. https:// doi.org/10.1007/s00702-008-0135-3

Araki R, Uda M, Hoki Y, Sunayama M, Nakamura M, Ando S et al (2013) Negligible immunogenicity of terminally differentiated cells derived from induced pluripotent or embryonic stem cells. Nature 494:100-104

Arber C, Lovejoy C, Wray S (2017) Stem cell models of Alzheimer's disease: progress and challenges. Alz Res Ther 9(1):42. https://doi.org/10.1 186/s13195-017-0268-4

Avinash K, Malaippan S, Dooraiswamy JN (2017) Methods of isolation and characterization of stem cells from different regions of oral cavity using markers: a systematic review. Int J Stem Cells 10(1):12-20

Baig AM (2014) Designer's microglia with novel delivery system in neurodegenerative diseases. Medic Hypo 83(4):510-512

Baig AM, Khan NA (2014) Novel chemotherapeutic strategies in the management of primary amoebic meningoencephalitis due to Naegleria fowleri. CNS Neurosci\& Therap 20(3):289-290

Bales KR, Tzavara ET, Wu S, Wade MR, Bymaster FP, Paul SM, Nomikos GG (2006) Cholinergc dysfunction in a mouse model of Alzheimer disease is reversed by an anti-Ab antibody. J Clin Invest 116:825-832

Bali P, Lahiri DK, Banik A, Nehru B, Anand A. Potential for stem cells therapy in Alzheimer's Disease: do neurotrophic factors play critical role? Curr Alzheimer Res. 2017; 14 (2)

Bang OY, Kim EH, Cha JM, Moon GJ (2016) Adult stem cell therapy for stroke: challenges and progress. J of Stroke 18(3):256-266

Banik A, Brown RE, Bamburg J, Lahiri DK, Khurana D, et al. Translation of preclinical studies into successful clinical trials for Alzheimer's disease: what are the roadblocks and how can they be overcome? J Alzheimer's Dis. 2015; 47(4)

Bekris LM, Yu CE, Bird TD, Tsuang DW (2010) Genetics of Alzheimer disease. J Geriatr Psychiatry Neurol 23

Bianco P, Cao X, Frenette PS, Mao JJ, Robey PG, Simmons PJ et al (2013) The meaning, the sense and the significance: translating the science of mesenchymal stem cells into medicine. Nat Med 19:35-42

Bissonnette CJ, Lyass L, Bhattacharyya BJ, Belmadani A, Miller RJ, Kessler JA (2011) The controlled generation of functional basal forebrain cholinergic neurons from human embryonic stem cells. Stem Cells 29(5):802-811

Blurton-Jones M, Kitazawa M, Martinez-Coria H, Castello NA, Müller FJ, Loring JF, et al. Neural stem cells improve cognition via BDNF in a transgenic model of Alzheimer disease. Proc. Natl. Acad. Sci. 2009; U.S.A. 106, 13594-13599

Blurton-Jones M, Spencer B, Michael S, Castello NA, Agazaryan AA et al (2014) Neural stem cells genetically modified to express neprilysin reduce pathology in Alzheimer transgenic models. Stem Cell Res Ther 5:46

Bock C, Kiskinis E, Verstappen G, Gu H, Boulting G, Smith ZD et al (2011) Reference maps of human ES and iPS cell variation enable high throughput characterization of pluripotent cell lines. Cell 144:439-452

Bonab MM, Alimoghaddam K, Talebian F, Ghaffari SH, Ghavamzadeh A, Nikbin B (2006) Aging of mesenchymal stem cell in vitro. BMC Cell Biol 7:14

Bonaguidi MA, Wheeler MA, Shapiro JS, Stadel RP, Sun GJ, Ming G (2011) In vivo clonal analysis reveals self-renewing and multipotent adult neural stem cell characteristics. Cell 145(7):1142-1155

Borai IH, Ezz MK, Rizk MZ, Ali HF, El Sherbiny M, Matloub AA, Fouad GI (2017) Therapeutic impact of grape leaves polyphenols on certain biochemical and neurological markers in $\mathrm{AlCl}_{3}$-induced Alzheimer's disease. Biomed Pharmacother 93:837-851

Burns TC, Verfaillie CM, Low WC (2009) Stem cells for ischemic brain injury: a critical review. J Comp Neurol 515(1):125-144

Caplan Al, Dennis JE (2006) Mesenchymal stem cells as trophic mediators. J Cell Biochem 98:1076e84

Chang KA, Lee JH, Suh YH. Therapeutic potential of human adipose-derived stem cells in neurological disorders. J of Pharmaco Sci. 2014; 126 (4)

Chen H, Li Y, Lin X, Cui D, Cui C, Li H et al (2012) Functional disruption of human leukocyte antigen II in human embryonic stem cell. Biol Res 48:59

Chen Q, Nakajima A, Choi SH, Xiong X, Sisodia SS, Tang YP (2008) Adult neurogenesis is functionally associated with AD-like neurodegeneration. Neurobiol Dis 29(2):316-326

Chen WW, Blurton-Jones M (2012) Concise review: can stem cells be used to treat or model Alzheimer's disease? Stem Cells 30(12):2612-2618

Choi SS, Lee SR, Kim SU, Lee HJ (2014) Alzheimer's disease and stem cell therapy. Exp Neurobiol 23(1):45-52 
Ciervo Y, Ning K, Jun X, Shaw PJ, Mead RJ. Advances, challenges, and future directions for stem cell therapy in amyotrophic lateral sclerosis. Mol Neurodegener. 2017; 12(1):85. Published 2017 Nov 13. https://doi.org/10.1186/s13024-017-0227-3

Confaloni A, Tosto G, Tata AM (2016) Promising therapies for Alzheimer's disease. Curr Pharm Des 22

Coric $\mathrm{V}$, van Dyck $\mathrm{CH}$, Salloway $\mathrm{S}$ et al. Safety and tolerability of the $\gamma$-secretase inhibitor avagacestat in a phase 2 study of mild to moderate Alzheimer disease. Arch of Neuro. 2012; 69 (11)

Coyle J, Kershaw P (2001) Galantamine, a cholinesterase inhibitor that allosterically modulates nicotinic receptors: effects on the course of Alzheimer's disease. Biol Psych 49

Cuervo AM Chaperone-mediated autophagy: selectivity pays off. Trends Endocrinol Metab. 2010;21:142-50.

Cummings J, Lee G, Mortsdorf T, Ritter A, Zhong K. Alzheimer's disease drug development pipeline: 2017. Alzheimers Dement. Transl Res Clin Interv. 2017; 3

Darlington D, Deng J, Giunta B et al (2013) Multiple low-dose infusions of human umbilical cord blood cells improve cognitive impairments and reduce amyloid-beta-associated neuropathology in Alzheimer mice. Stem Cells Dev 22(3):412-421

De Becker A, Riet IV (2016) Homing and migration of mesenchymal stromal cells: how to improve the efficacy of cell therapy? World J Stem Cells 8(3):73-87

Divya MS, Roshin GE, Divya TS et al (2012) Umbilical cord blood-derived mesenchymal stem cells consist of a unique population of progenitors coexpressing mesenchymal stem cell and neuronal markers capable of instantaneous neuronal differentiation. Stem Cell Rese \& Therap 3(6):57

Dominguez G, Dagnas M, Decorte L, Vandesquille M, Belzung C, Beracochea D, Mons N. Rescuing prefrontal CAMP-CREB pathway reverses working memory deficits during withdrawal from prolonged alcohol exposure. Brain Struct Funct. 2016;221(2):865-77.

Donovan MH, Yazdani U, Norris RD, Games D, German DC, Eisch AJ (2006) Decreased adult hippocampal neurogenesis in the PDAPP mouse model of Alzheimer's disease. J Comp Neurol 495(1):70-83

Doody RS, Raman R, Farlow M et al. A phase 3 trial of semagacestat for treatment of Alzheimer's disease. N Eng J Med. 2013; 369

Doraiswamy PM, Sperling RA, Johnson K, Reiman EM, Wong TZ, Sabbagh MN, et al. Florbetapir F 18 amyloid PET and 36-month cognitive decline: a prospective multicenter study. Molec Psych. 2014; 19(9)

Drela K, Siedlecka P, Sarnowska A, Domanska-Janik K (2013) Human mesenchymal stem cells in the treatment of neurological diseases. Acta Neurobiol Exp 73:38-56

Duan L, Bhattacharyya BJ, Belmadani A, Pan L, Miller RJ, Kessler JA. Stem cell derived basal forebrain cholinergic neurons from Alzheimer's disease patients are more susceptible to cell death. Mol Neurodegener. 2014;9(1):3.

Duncan T, Valenzuela M. Alzheimer's disease, dementia, and stem cell therapy. Stem Cell Res \& Ther. 2017; 8 (1)

Dunnett SB, Rosser AE (2014) Challenges for taking primary and stem cells into clinical neurotransplantation trials for neurodegenerative disease. Neurob of Disease 61:79-89

El Andaloussi S, Mäger I, Breakefield XO, Wood MJA (2013) Extracellular vesicles: biology and emerging therapeutic opportunities. Nat Rev Drug Discov 12: 347-357. https://doi.org/10.1038/nrd3978

Enciu AM, Nicolescu MI, Manole CG, Mureşanu DF, Popescu LM, Popescu BO (2011) Neuroregeneration in neurodegenerative disorders. BMC Neurol 11(1):75

Eriksdotter-Jönhagen M, Linderoth B, Lind G, Aladellie L, Almkvist O, Andreasen $\mathrm{N}$, et al. Encapsulated cell biodelivery of nerve growth factor to the basal forebrain in patients with Alzheimer's disease. Dement. Geriatr. Cogn. Disord. 2012; 33, 18-28.

Eriksson PS, Perfilieva E, Björk-Eriksson T, Alborn AM, Nordborg C, Peterson DA et al (1998) Neurogenesis in the adult human hippocampus. Nat Med 4

Fabian C, Naaldijk Y, Leovsky C, Johnson AA, Rudolph L, Jaeger C et al (2017) Distribution pattern following systemic mesenchymal stem cell injection depends on the age of the recipient and neuronal health. Stem Cell Res Ther 8:85. https://doi.org/10.1186/s13287-017-0533-2

Fan X, Sun D, Tang X, Cai Y, Yin ZQ, Xu H (2014) Stem-cell challenges in the treatment of Alzheimer's disease: a long way from bench to bedside. Rev. 34(5):957-978

Fang Y, Gao T, Zhang B, Pu J (2018) Recent advances: decoding Alzheimer's disease with stem cells. Front Aging Neurosci 10:77. https://doi.org/10.3389/ fnagi.2018.00077

Fatt M, Hsu K, He L, Wondisford F, Miller FD et al (2015) Metformin acts on two different molecular pathways to enhance adult neural precursor proliferation/self-renewal and differentiation. Stem Cell Rep. 5:988-995. https://doi.org/10.1016/j.stemcr.2015.10.014

Feng Z, Zhao G, Yu L (2009) Neural stem cells and Alzheimer's disease: challenges and hope. Am J Alzheimers Dis Other Demen 24:52-57

Ferreiro E, Baldeiras I, Ferreira IL, Costa RO, Rego AC, Pereira CF, Oliveira CR (2012) Mitochondrial and endoplasmic reticulum-associated oxidative stress in Alzheimer's disease: from pathogenesis to biomarkers. Int J of Cell Bio 735206

Fong CY, Gauthaman K, Bongso A (2010) Teratomas from pluripotent stem cells: a clinical hurdle. J Cell Biochem 111:769-781

Freed CR, Breeze RE, Rosenberg NL, Schneck SA, Kriek E, Qi JX et al (1992) Survival of implanted fetal dopamine cells and neurologic improvement 12 to 46 months after transplantation for Parkinson's disease. N Engl J Med 327:1549-1555

Frese L, Dijkman PE, Hoerstrup SP (2016) Adipose tissue-derived stem cells in regenerative medicine. Transfus Med Hemother 43(4):268-274

Frith JE, Thomson B, Genever PG (2010) Dynamic three-dimensional culture methods enhance mesenchymal stem cell properties and increase therapeutic potential. Tissue Eng Part C Methods 16:735-749

Fujiwara N, Shimizu J, Takai K, Arimitsu N, Saito A, Kono T et al (2013) Restoration of spatial memory dysfunction of human APP transgenic mice by transplantation of neuronal precursors derived from human iPS cells. Neurosci Lett 557:129-134

Gadadhar A, Marr R, Lazarov O (2011) Presenilin-1 regulates neural progenitor cell differentiation in the adult brain. J Neurosci 31:2615-2623. https://doi.org/10. 1523/JNEUROSCI.4767-10.2011

Gage FH (2002) Neurogenesis in the adult brain. J Neurosci 22:612-613

Garcia KO, Ornellas FLM, Martin PKM, Patti CL et al (2014) Therapeutic effects of the transplantation of VEGF overexpressing bone marrow mesenchymal stem cells in the hippocampus of murine model of Alzheimer's disease. Front Aging Neurosci 6:30. https://doi.org/10.3389/fnagi.2014.00030

Garcia P, Youssef I, Utvik JK, Florent-Béchard S, Barthélémy V, Malaplate-Armand C, et al. Ciliary neurotrophic factor cell-based delivery prevents synaptic impairment and improves memory in mouse models of Alzheimer's disease. J. Neurosci. 2010; 30, 7516-7527. doi: https://doi.org/10.1523/JNEUROSCI.4182-09.2010

Ghosal K, Stathopoulos A, Pimplikar SW (2010) APP intracellular domain impairs adult neurogenesis in transgenic mice by inducing neuroinflammation. PLoS One 5:e11866. https://doi.org/10.1371/journal.pone.0011866

Giocomo LM, Moser MB, Moser El (2011) Computational models of grid cells. Neuron 71:589-603

Giunti D, Parodi B, Usai C, Vergani L, Casazza S, Bruzzone S et al (2012) Mesenchymal stem cells shape microglia effector functions through the release of CX3CL1. Stem Cells 30:2044-2053

González H, Pacheco R (2014) T-cell-mediated regulation of neuroinflammation involved in neurodegenerative diseases. J. Neuroinfl. 11:201

Gratwicke J, Kahan J, Zrinzo L, Hariz M, Limousin P, Foltynie T, Jahanshahi M (2013) The nucleus basalis of Meynert: a new target for deep brain stimulation in dementia? Neurosci Biobehav Rev 37:2676-2688

Grezella C, Fernandez-Rebollo E, Franzen J, Ventura Ferreira MS, Beier F, Wagner W (2018) Effects of senolytic drugs on human mesenchymal stromal cells. Stem Cell Res Ther 9:108

Gutiérrez-Fernández M, Rodríguez-Frutos B, Ramos-Cejudo J et al (2013) Effects of intravenous administration of allogenic bone marrow- and adipose tissuederived mesenchymal stem cells on functional recovery and brain repair markers in experimental ischemic stroke. Stem Cell Res Therap 4(1):11

Hardy J. The amyloid hypothesis for Alzheimer's disease: a critical reappraisal. J Neurochem. 2009; 110(4)

Haughey NJ, Liu D, Nath A, Borchard AC, Mattson MP (2002) Disruption of neurogenesis in the subventricular zone of adult mice, and in human cortical neuronal precursor cells in culture, by amyloid beta-peptide: implications for the pathogenesis of Alzheimer's disease. NLM 1(2):125-135

Heppner FL, Ransohoff RM, Becher B (2015) Immune attack: the role of inflammation in Alzheimer disease. Nat Rev Neurosci 16:358-372. https://doi. org/10.1038/nrn3880

Hermann A, Storch A (2013) Induced neural stem cells (iNSCs) in neurodegenerative diseases. Neural Transm 120(1):S19-S25

Hescham S, Lim LW, Jahanshahi A, Blokland A, Temel Y (2013) Deep brain stimulation in dementia-related disorders. Neurosci Biobehav Rev 37:2666-2675

Hollands C, Bartolotti N, Lazarov O (2016) Alzheimer's disease and hippocampal adult neurogenesis; exploring shared mechanisms. Front Neurosci 10:178. https://doi.org/10.3389/fnins.2016.00178 
Horgusluoglu E, Nudelman K, Nho K, Saykin AJ (2017) Adult neurogenesis and neurodegenerative diseases: a systems biology perspective. Am J Med Genet B Neuropsych Genet 174:93-112. https://doi.org/10.1002/ajmg.b.32429

Hoveizi E, Mohammadi T, Moazedi AA, Eskandary A, Zamani N (2018) Transplanted neural-like cells improve memory and Alzheimer-like pathology in a rat model. Cytotherapy. https://doi.org/10.1016/j.jcyt.2018.03.036

Hsun Y, Yang K (2018) Aging of mesenchymal stem cells: implication in regenerative medicine. Reg Ther 9:120-122

Huang Y, Mucke L. Alzheimer mechanisms and therapeutic strategies. Cell 2012; 148 (6)

Hunsberger JG, Rao M, Kurtzberg J et al (2016) Accelerating stem cell trials for Alzheimer's disease. Lancet Neurol 15(2):219-230

Igarashi KM, Lu L, Colgin LL, Moser MB, Moser El (2014) Coordination of entorhinal-hippocampal ensemble activity during associative learning. Nature 510:143-147

Ikegame Y, Yamashita K, Hayashi S et al (2011) Comparison of mesenchymal stem cells from adipose tissue and bone marrow for ischemic stroke therapy. Cytotherapy 13(6):675-685

James OG, Doraiswamy PM, Borges-Neto S (2015) PET imaging of tau pathology in Alzheimer's disease and tauopathies. Front Neuro 6

Jin K, Galvan V (2007) Endogenous neural stem cells in the adult brain. J Neurolmmune Pharmacol 2:236-242

Jin K, Zhu Y, Sun Y, Mao XO, Xie L, Greenberg DA. Vascular endothelial growth factor (VEGF) stimulates neurogenesis in vitro and in vivo. Proc Natl Acad Sci. 2002:99(18):11946-50.

Juranek JK, Geddis MS, Song F, Zhang J, Garcia J, Rosario R et al (2013) RAGE deficiency improves postinjury sciatic nerve regeneration in type 1 diabetic mice. Diabetes 62:931-943

Kanno H (2013) Regenerative therapy for neuronal diseases with transplantation of somatic stem cells. World J Stem Cells 5(4):163-171

Katsuda T, Kosaka N, Takeshita F, Ochiya T The therapeutic potential of mesenchymal stem cell-derived extracellular vesicles. Proteom 2013a;13: 1637-53. https://doi.org/10.1002/pmic.201200373

Katsuda T, Tsuchiya R, Kosaka N, Yoshioka Y, Takagaki K, Oki K, et al Human adipose tissue-derived mesenchymal stem cells secrete functional neprilysin-bound exosomes. Sci. Rep. 2013b;3:1197 https://doi.org/10. 1038/srep01197.

Khan SS, Bloom GS (2016) Tau: the center of a signaling nexus in Alzheimer's disease. Front Neurosci

Kile S, Au W, C Parise, Rose K, Donnel T, Hankins A, Chan M, et al IVIG treatment of mild cognitive impairment due to Alzheimer's disease: a randomized doble-blinded exploratory study of the effect on brain atrophy, cognition and conversion to dementia. J Neur, Neurosurg \& Psych. 2017; 88 (2)

Kim DH, Lee D, Chang EH, Kim JH, Hwang JW et al (2015) GDF-15 secreted from human umbilical cord blood mesenchymal stem cells delivered through the cerebrospinal fluid promotes hippocampal neurogenesis and synaptic activity in an Alzheimer's disease model. Stem Cells Dev 24:2378-2390. https://doi.org/10.1089/scd.2014.0487

Kim JY, Kim DH, Kim JH, Lee D, Jeon HB, Kwon SJ et al (2012) Soluble intracellular adhesion molecule-1 secreted by human umbilical cord blood-derived mesenchymal stem cell reduces amyloid-b plaques. Cell Death Differ 19:680691. https://doi.org/10.1038/cdd.2011.140

Kim SU, Lee HJ, Kim YB (2013) Neural stem cell-based treatment for neurodegenerative diseases. Neuropath. 33:491-504Kimura N. Diabetes mellitus induces alzheimer's disease pathology: histopathological evidence from animal models. Int J Mol Sci. 2016; 17 (4)

King NM, Perrin J (2014) Ethical issues in stem cell research and therapy. Stem Cell Res Ther 5(4):85. https://doi.org/10.1186/scrt474Klempin F, Kempermann G (2007) Adult hippocampal neurogenesis and aging. Eur Arch Psychiatry Clin Neurosci 257:271-280. https://doi.org/10.1007/s00406-007-0731-5

Klinge PM, Harmening K, Miller MC, Heile A et al (2011) Encapsulated native and glucagon-like peptide-1 transfected human mesenchymal stem cells in a transgenic mouse model of Alzheimer's disease. Neurosci Lett 497: 6-10. https://doi.org/10.1016/j.neulet.2011.03.092

Kocaoglu M, Korucu M, Civlan S, Ozdemir K, Ozdemir M et al (2014) Stem cell therapy in the treatment of neurological diseases. Brain Disord Ther 3. https://doi.org/10.4172/2168-975X.1000132

Krencik R, Weick JP, Liu Y, Zhang Z, Zhang SC (2011) Specification of transplantable astroglial subtypes from human pluripotent stem cells. Nature Biotech 29(6):528-534

Kriks S, Shim JW, Piao J et al (2011) Dopamine neurons derived from human ES cells efficiently engraft in animal models of Parkinson's disease. Nature 480(7378):547-551
Kwak KA, Lee SP, Yang JY, Park YS (2018; Article ID 6392986, 14 pages) Current perspectives regarding stem cell-based therapy for Alzheimer's disease. Stem Cells Int https://doi.org/10.1155/2018/6392986

Lai AY, Mc Laurin J. Inhibition of amyloid-beta peptide aggregation rescues the autophagic deficits in the TgCRND8 mouse model of Alzheimer disease. Biochim. Biophys. Acta. 2012; 1822:1629-37; https://doi.org/10.1016/.jbbadis.2012.07.003

Lanza RP, Atala A (2014) Essentials of stem cell biology, Second Edition. Elsevier/ Academic Press, Amsterdam

Laroni A, de RosboNicole K, Uccelli A (2015) Mesenchymal stem cells for the treatment of neurological diseases: immunoregulation beyond neuroprotection. Imm Lett 168:183-190

Lee H, Shamy GA, Elkabetz Y et al (2007) Directed differentiation and transplantation of human embryonic stem cell-derived motoneurons. Stem Cells 25(8):1931-1939

Lee HJ, Lee JK, Lee H, Carter JE, Chang JW, Oh W et al (2012b) Human umbilical cord blood-derived mesenchymal stem cells improve neuropathology and cognitive impairment in an Alzheimer's disease mouse model through modulation of neuroinflammation. Neurobiol Aging 33:588-602

Lee IS, Jung K, Kim IS, Lee H et al (2015) Human neural stem cells alleviate Alzheimer-like pathology in a mouse model. Mol Neurodegener 10:38

Lee $\mathrm{H}$, Oh IH, Lim HK (2016) Stem cell therapy: a prospective treatment for Alzheimer's disease. Psych Investig 13(6):583-589

Lee JK, Jin HK, Bae JS (2009) Bone marrow-derived mesenchymal stem cells reduce brain amyloid-[beta] deposition and accelerate the activation of microglia in an acutely induced Alzheimer's disease mouse model. Neurosci Lett 450:136-141

Lee JK, Jin HK, Endo S, Schuchman EH, Carter JE, Bae JS (2010) Intracerebral transplantation of bone marrow-derived mesenchymal stem cells reduces amyloid-beta deposition and rescues memory deficits in Alzheimer's disease mice by modulation of immune responses. Stem Cells 28(2):329-343

Lee JK, Schuchman EH, Jin HK, Bae JS (2012a) Soluble CCL5 derived from bone marrow derived mesenchymal stem cells and activated by amyloid $\beta$ ameliorates Alzheimer's disease in mice by recruiting bone marrow-induced microglia immune responses. Stem Cells 30(7):1544-1555

Lee Y, Kim J, Jang S, Oh S (2013) Administration of phytoceramide enhances memory and upregulates the expression of pCREB and BDNF in hippocampus of mice. Biomol Ther 21(3):229-233

Lerou P (2011) Embryonic stem cell derivation from human embryos. Methods Mol Biol 767:31-35

Lewis CM, Suzuki M (2014) Therapeutic applications of mesenchymal stem cells for amyotrophic lateral sclerosis. Stem Cell Res Ther 5(2):32

Li B, Piao CS, Liu XY et al (2010) Brain self-protection: the role of endogenous neural progenitor cells in adult brain after cerebral cortical ischemia. Brain Res 1327:91-102

Li M, Guo K, Ikehara S (2014) Stem cell treatment for Alzheimer's disease. Int J Mol Sci 15:19226-19238. https://doi.org/10.3390/ijms151019226

Li Q, Ford MC, Lavik EB, Madri JA (2006) Modeling the neurovascular niche: VEGFand BDNF-mediated cross-talk between neural stem cells and endothelial cells: an in vitro study. J Neurosci Res 84:1656-1668

Li WY, Choi YJ, Lee PH, Huh K, Kang YM, Kim HS et al (2008) Mesenchymal stem cells for ischemic stroke: changes in effects after ex vivo culturing. Cell Transplant 17: 1045-1059

Li XY, Bao XJ, Wang RZ (2015) Potential of neural stem cell-based therapies for Alzheimer's disease. J of Neurosc Res 93:1313-1324

Lilja AM, Malmsten L, Röjdner J, et al. Neural stem cell transplant-induced effect on neurogenesis and cognition in Alzheimer Tg2576 mice is inhibited by concomitant treatment with amyloid-lowering or cholinergic a7 nicotinic receptor drugs. Neu. Plast. 2015; Article ID 370432, 13 pages

Limke TL, Rao MS (2003) Neural stem cell therapy in the aging brain: pitfalls and possibilities. J Hematother Stem Cell Res 12:615-623

Liras A (2010) Future research and therapeutic applications of human stem cells: general, regulatory, and bioethical aspects. J Transl Med 8(1):131

Liu AKL. Stem cell therapy for Alzheimer's disease: hype or hope?, Biosci. Horiz. 2013; 6, article hzt011

Lomax GP, Hull SC, Lowenthal J, Rao M, Isasi R (2013) The DISCUSS project: induced pluripotent stem cell lines from previously collected research biospecimens and informed consent: points to consider. Stem Cells Trans. Med. 2(10):727-730

Lopez-Toledano MA, Shelanski ML (2007) Increased neurogenesis in young transgenic mice overexpressing human APP Sw, Ind.J Alzheimer's Dis 12(3):229-240 
Lunn JS, Sakowski SA, Hur J, Feldman EL (2011) Stem cell technology for neurodegenerative diseases. Ann of Neuro 70(3):353-361

Luo L, He Y, Wang $X$, et al. Potential roles of dental pulp stem cells in neural regeneration and repair. Stem Cells Int. 2018; Article ID 1731289, 15 pages, https://doi.org/10.1155/2018/1731289

Luque-Contreras D, Carvajal K, Toral-Rios D, Franco-Bocanegra D, Campos-Peña V. Oxidative stress and.metabolic syndrome: cause or consequence of Alzheimer's disease?. Oxid Med Cell Longev. 2014. p. 11.

Ma JF, Huang Y, Chen SD, Halliday G (2010) Immunohistochemical evidence for macroautophagy in neurones and endothelial cells in Alzheimer's disease. Neuropathol Appl Neurobiol 36:312-319

Ma T, Gong K, Ao Q, Yan Y, Song B, Huang H (2013) Intracerebral transplantation of adipose-derived mesenchymal stem cells alternatively activates microglia and ameliorates neuropathological deficits in Alzheimer's disease mice. Cell Transplant 22(1):S113-S126

Manganas LN, Zhang X, Li Y, Hazel RD, Smith SD, Wagshul ME et al (2007) Magnetic resonance spectroscopy identifies neural progenitor cells in the live human brain. Scie. 318:980-985

Marchetto MC, Yeo GW, Kainohana O, Marsala M, Gage FH, Muotri AR (2009) Transcriptional signature and memory retention of human-induced pluripotent stem cells. PLoS One 4:e7076

Marks PW, Witten CM, Califf RM (2017) Clarifying stem-cell therapy's benefits and risks. N Engl J Med 376

Martínez-Morales PL, Revilla A, Ocaña I et al (2013) Progress in stem cell therapy for major human neurological disorders. Stem Cell Rev and Rep 9(5):685-699

Martino G, Pluchino S (2006) The therapeutic potential of neural stem cells. Nat Rev Neurosci 7:395-406. https://doi.org/10.1038/nrn1908

Mead B, Logan A, Berry M, Leadbeater W, Scheven BA (2017) Concise review: dental pulp stem cells: a novel cell therapy for retinal and central nervous system repair. Stem Cells 35:61-67. https://doi.org/10.1002/stem.2398

Melchor JP, Pawlak R, Strickland S (2003) The tissue plasminogen activatorplasminogen proteolytic cascade accelerates amyloid-beta degradation and inhibit Abeta-induced neurodegeneration. J Neurosci 23:8867-8871

Meraz-Ríos MA, Toral-Rios D, Franco-Bocanegra D, Villeda-Hernández J, Campos-Peña V (2013) Inflammatory process in Alzheimer's disease. Front Int Neurosci 7

Meyer JR (2008) The significance of induced pluripotent stem cells for basic research and clinical therapy. J Med Ethics 34:849-851

Miller BC, Eckman EA, Sambamurti K, Dobbs N, Chow KM, Eckman CB, Hersh LB, Thiele DL (2003) Amyloid-beta peptide levels in brain are inversely correlated with insulysin activity levels in vivo. Proc Natl Acad Sci U S A 100:6221-6226

Millington C, Sonego S, Karunaweera N, Rangel A, Aldrich-Wright J, et al. Chronic neuroinflammation in Alzheimer's disease: new perspectives on animal models and promising candidate drugs. BioMed Rese. Inter. 2014; Article ID 309129

Ming G, Song H (2005) Adult neurogenesis in the mammalian central nervous system. Annu Rev Neurosci 28:223-250

Misra S, Chopra K, Saikia UN, Sinha VR, Sehgal R, Modi M, Medhi B (2016) Effect of mesenchymal stem cells and galantamine nanoparticles in rat model of Alzheimer's disease. Regen Med 11(7):629-646

Moghadam FH, Alaie H, Karbalaie K, Tanhaei S, Esfahani MHN, Baharvand H (2009) Transplantation of primed or unprimed mouse embryonic stem cellderived neural precursor cells improves cognitive function in Alzheimerian rats. Different. 78:59-68

Monacelli F and Rosa G. Cholinesterase inhibitors: cardioprotection in Alzheimer's disease. J Alzheimers Dis. 2014; 42(4)

Mu Y, Gage FH (2011) Adult hippocampal neurogenesis and its role in Alzheimer's disease. Mol Neurodegener 6(1):85

Mucke L (2009) Neuroscience: Alzheimer's disease. Nature 461:895-897

Naaldijk Y, Jäger C, Fabian C, Leovsky C, Blüher A, Rudolph L, Hinze A, Stolzing A (2017) Effect of systemic transplantation of bone marrow-derived mesenchymal stem cells on neuropathology markers in APP/PS1 Alzheimer mice. Neuropathol Appl Neurobiol 43:299-314

Naert G, Rivest S (2012) Hematopoietic CC-chemokine receptor 2 (CCR2) competent cells are protective for the cognitive impairments and amyloid pathology in a transgenic mouse model of Alzheimer's disease. Mol Med 18:297-313

Najar AH, Sneha KM, Ashok A, Babu S, Subramaniam AG, Kannan R, Viswanath B, Purushottam M, Varghese M et al (2018) Derivation of iPSC lines from two patients with familial Alzheimer's disease from India. Stem Cell Res 34:101370

Njie G, Kantorovich S, Astary GW, Green C, Zheng T, Semple-Rowland SL (2012) A preclinical assessment of neural stem cells as delivery vehicles for antiamyloid therapeutics. PLoS One 7:e34097

Nussbaum J, Minami E, Laflamme MA et al (2007) Transplantation of undifferentiated murine embryonic stem cells in the heart: teratoma formation and immune response. FASEB J 21:1345-1357

Oh SH, Kim HN, Park HJ, Shin JY, Lee PH (2015) Mesenchymal stem cells increase hippocampal neurogenesis and neuronal differentiation by enhancing the Wnt signaling pathway in an Alzheimer's disease model. Cell Transplant 24(6):1097-1109

Okita K, Ichisaka T, Yamanaka S (2007) Generation of germline-competent induced pluripotent stem cells. Nature 448(7151):313-317

Pallas M, Camins A (2006) Molecular and biochemical features in Alzheimer's disease. Curr Pharm Des 12

Pang ZP, Yang N, Vierbuchen T, Ostermeier A, Fuentes DR, Yang TQ et al (2011) Induction of human neuronal cells by defined transcription factors. Nature 476:220-223

Panopoulos AD, Ruiz S, Belmonte IJC (2011) iPSCs: induced back to controversy. Cell Stem Cell 8(4):347-348

Pappas DJ, Gourraud PA, Le Gall C et al (2015) Proceedings: human leukocyte antigen haplo-homozygous induced pluripotent stem cell haplobank modeled after the California population: evaluating matching in a multiethnic and admixed population. Stem Cells Trans Med 4(5):413-418

Park D, Lee HJ, Joo SS, Lim I, Matsumoto A, Tooyama I et al (2012) Human neural stem cells over-expressing choline acetyltransferase restore cognition in rat model of cognitive dysfunction. Exp Neurol 234(2):521-526

Park D, Yang YH, Bae DK et al (2013) Improvement of cognitive function and physical activity of aging mice by human neural stem cells over-expressing choline acetyltransferase. Neurobiol Ag 34:2639-2646

Parr C, Carzaniga R, Gentleman SM, Van Leuven F, Walter J, Sastre M (2012) Glycogen synthase kinase 3 inhibition promotes lysosomal biogenesis and autophagic degradation of the amyloid- $\beta$ precursor protein. Mol Cell Biol 32:4410-4418

Paspala SA, Balaji AB, Nyamath P, Ahmed KS, Khan AA et al (2009) Neural stem cells \& supporting cells-the new therapeutic tools for the treatment of spinal cord injury. Indian J Med Res 130:379-391

Pavlov VA, Tracey KJ (2006) Controlling inflammation: the cholinergic antiinflammatory pathway. Bioch Soc transact 34:1037-1040

Pen $A E$, Jensen UB. Current status of treating neurodegenerative disease with induced pluripotent stem cells. Acta Neuro Scand. 2017; 135 (1)

Perneczky R, Alexopoulos P. Cerebrospinal fluid BACE1 activity and markers of amyloid precursor protein metabolism and axonal degeneration in Alzheimer's disease. Alz \& Dem. 2014; 10(0)

Peroni D, Scambi I, Pasini A et al (2008) Stem molecular signature of adiposederived stromal cells. Exp Cell Res 314(3):603-615

Popovic N, Brundin P (2006) Therapeutic potential of controlled drug delivery systems in neurodegenerative diseases. Int J Pharm 314

Portelius E, Dean RA, Gustavsson MK, Andreasson U, Zetterberg H, Siemers E et al (2010) A novel Abeta isoform pattern in CSF reflects gamma-secretase inhibition in Alzheimer disease. Alz Res Ther. 2

Qu T, Brannen CL, Kim HM, Sugaya K (2001) Human neural stem cells improve cognitive function of aged brain. Neuroreport. 12:1127-1132

Querfurth HW, La Ferla FM. Alzheimer 's disease. The New Eng J of Med. 2010; 362 (4)

Ra JC, Shin IS, Kim SH et al (2011) Safety of intravenous infusion of human adipose tissue-derived mesenchymal stem cells in animals and humans. Stem Cells Dev 20(8):1297-1308

Ratajczak MZ, Jadczyk T, Pedziwiatr D, Wojakowski W (2014) New advances in stem cell research: practical implications for regenerative medicine. Pol Arch Med Wewn 124:417-426

Record M, Subra C, Silvente-Poirot S, Poirot M (2011) Exosomes as intercellular signalosomes and pharmacological effectors. Biochem Pharmacol 81:11711182. https://doi.org/10.1016/j.bcp.2011.02.011

Reitz C, Brayne C, Mayeux R. Epidemiology of Alzheimer's disease. Nature Rev Neuro. 2011; 7 (3)

Ryu JK, Cho T, Wang YT et al (2009) Neural progenitor cells attenuate inflammatory reactivity and neuronal loss in an animal model of inflamed AD brain. J Neuroinfl 6:39

Salloway S, Sperling R, Fox NC, Blennow K, Klunk W, Raskind M et al (2014) Two phase 3 trials of bapineuzumab in mild-to-moderate Alzheimer's disease. N Engl J Med 370. https://doi.org/10.1056/NEJMoa1304839 
Sart S, Tsai AC, Li Y, Ma T (2014) Three-dimensional aggregates of mesenchymal stem cells: cellular mechanisms, biological properties, and applications. Tissue Eng Part B Rev 20:365-380

Schipper HM (2011) Apolipoprotein E: implications for AD neurobiology, epidemiology and risk assessment. Neurobiol Aging 32

Schöndorf DC, Elschami M, Schieck M, Ercan-Herbst E, Weber C, Riesinger Y, Kalman S, Steinemann D, Ehrnhoefer DE (2018) Generation of an induced pluripotent stem cell cohort suitable to investigate sporadic Alzheimer's disease. Stem Cell Res 34:101351

Shin JY, Park HJ, Kim HN, Oh SH, Bae JS, Ha HJ et al (2014) Mesenchymal stem cells enhance autophagy and increase b-amyloid clearance in Alzheimer disease models. Autophagy 10:32-44. https://doi.org/10.4161/auto.26508

Shroff G (2018) A review on stem cell therapy for multiple sclerosis: special focus on human embryonic stem cells. Stem Cells and Cloning: Adv and App 11

Sibov TT, Pavon LF, Miyaki LA, Mamani JB, Nucci LP, Alvarim LT, Gamarra L (2014) Umbilical cord mesenchymal stem cells labeled with multimodal iron oxide nanoparticles with fluorescent and magnetic properties: application for in vivo cell tracking. Int J Nanomedicine 9:337

Sommer AG, Rozelle SS, Sullivan S, Mills JA, Park SM, Smith BW et al (2012) Generation of human induced pluripotent stem cells from peripheral blood using the STEMCCA lentiviral vector. J Vis Exp 68. https://doi.org/10.3791/4327

Song JH, Yu JT, Tan L (2015) Brain-derived neurotrophic factor in Alzheimer's disease: risk, mechanisms, and therapy. Mol Neurobiol 52(3):1477-1493

Sperling RA, Aisen PS, Beckett LA et al. Toward defining the preclinical stages of Alzheimer's disease: recommendations from the National Institute on AgingAlzheimer's Association workgroups on diagnostic guidelines for Alzheimer's disease. Alz Dement 2011;7(3)

Spuch C, Antequera D, Portero A, Orive G, Hernández RM, Molina JA et al (2010) The effect of encapsulated VEGF-secreting cells on brain amyloid load and behavioral impairment in a mouse model of Alzheimer's disease. Biomaterials 31:5608-5618. https://doi.org/10.1016/j.biomaterials.2010.03.042

Stadtfeld M, Hochedlinger K (2010) Induced pluripotency: history, mechanisms, and applications. Genes Dev 24(20):2239-2263

Stella F, Radanovic M, Canineu PR, de Paula VJ, Forlenza OV (2015) Anti-dementia medications: current prescriptions in clinical practice and new agents in progress. Ther Adv Drug Saf 6

Stensola H, Stensola T, Solstad T, Froland K, Moser MB, Moser El (2012) The entorhinal grid map is discretized. Nature 492:72-78

Stephanopoulos N, Freeman R, North HA, Sur S, Jeong SJ, Tantakitti F, Stupp SI (2014) Bioactive DNA-peptide nanotubes enhance the differentiation of neural stem cells into neurons. Nano Lett 15(1):603-609

Sullivan R, Duncan K, Dailey T, Kaneko Y, Tajiri N, Borlongan CVA (2015) Possible new focus for stroke treatment-migrating stem cells. Ex Op on Bio Ther 15(7):949-958

Sun C, Shao J, Su L, Zhao J, Bi J, Yang S et al (2013) Cholinergic neuron-like cells derived from bone marrow stromal cells induced by tricyclodecane-9-ylxanthogenate promote functional recovery and neural protection after spinal cord injury. Cell Transplant 22:961-975

Suzuki A, Fukushima H, Mukawa T et al (2011) Upregulation of CREB-mediated transcription enhances both short- and long-term memory. J Neurosci 31(24):8786-8802

Swerdlow RH, Burns JM, Khan SM The Alzheimer's disease mitochondrial cascade hypothesis: progress and perspectives. Biochim Biophys Acta 2014;1842: 1219-31.

Szabo P, Relkin N, Weksler ME (2008) Natural human antibodies to amyloid $\beta$ peptide. Autoimmun Rev 7:415-420

Takahashi K, Yamanaka S (2006) Induction of pluripotent stem cells from mouse embryonic and adult fibroblast cultures by defined factors. Cell 126(4):663-76.

Takahashi K, Yasuhara T, Shingo T, Muraoka K, Kameda M et al (2008) Embryonic neural stem cells transplanted in middle cerebral artery occlusion model of rats demonstrated potent therapeutic effects, compared to adult neural stem cells. Brain Res 1234:172-182

Takamatsu K, Ikeda T, Haruta M et al (2014) Degradation of amyloid beta by human induced pluripotent stem cell derived macrophages expressing Neprilysin-2. Stem Cell Res 13(3):442-453

Tang J (2012) How close is the stem cell cure to the Alzheimer's disease: future and beyond? Neural Regen Res 7(1):66-71

Tang J, Xu H, Fan X, Li D, Rancourt D, Zhou G et al (2008) Embryonic stem cellderived neural precursor cells improve memory dysfunction in Abeta (1-40) injured rats. Neurosci Res 62:86-96
Tang Y, Le W (2016) Differential roles of M1 and M2 microglia in neurodegenerative diseases. Mol Neurobiol 53:1181-1194. https://doi.org/10. 1007/s12035-014-9070-5

Teixeira FG, Carvalho MM, Neves-Carvalho A, Panchalingam KM, Behie LA, Pinto L, Sousa N, Salgado AJ (2015) Secretome of mesenchymal progenitors from the umbilical cord acts as modulator of neural/glial proliferation and differentiation. Stem Cell Rev Rep 11:288-297

Tfilin M, Sudai E, Merenlender A, Gispan I, Yadid G, Turgeman G (2010) Mesenchymal stem cells increase hippocampal neurogenesis and counteract depressive-like behavior. Mol Psych 15:1164-1175

Tincera G, Mashkaryana V, Bhattaraia P, Kizil C (2016) Neural stem/progenitor cells in Alzheimer's disease. $Y$ j of bio and med 89

Tiwari SK, Agarwal S, Seth B, Yadav A, Nair S, Bhatnagar P, Patel DK (2013) Curcumin-loaded nanoparticles potently induce adult neurogenesis and reverse cognitive deficits in Alzheimer's disease model via canonical Wnt/ $\beta$ catenin pathway. ACS Nano 8(1):76-103

Tong LM, Fong H, Huang Y (2015) Stem cell therapy for Alzheimer's disease and related disorders: current status and future perspectives. Exp Mol Med 47:e15

Turgeman G (2015) The therapeutic potential of mesenchymal stem cells in Alzheimer,s disease: converging mechanisms. Neural Regen Res 10(5): 698-699

Veeraraghavalu K, Choi SH, Zhang X, Sisodia SS (2010) Presenilin 1 mutants impair the self-renewal and differentiation of adult murine subventricular zone-neuronal progenitors via cell-autonomous mechanisms involving notch signaling. J Neurosci 30(20):6903-6915

Volarevic V, Markovic BS, Gazdic M, et al. Ethical and safety issues of stem cellbased therapy. Int J Med Sci. 2018; 15(1):36-45. Published 2018 Jan 1. doi: https://doi.org/10.7150/ijms.21666

Voloboueva LA, Giffard RG (2011) Inflammation, mitochondria, and the inhibition of adult neurogenesis. J Neurosci Res 89:1989-1996

Wahlberg LU, Lind G, Almqvist PM, Kusk P, Tornøe J, Juliusson B, et al. Targeted delivery of nerve growth factor via encapsulated cell biodelivery in Alzheimer disease: a technology platform for restorative neurosurgery. J. Neurosurg. 2012; 117, 340-347. doi: https://doi.org/10.3171/2012.2.JNS11714

Walsh DM, Selkoe DJ (2004) Deciphering the molecular basis of memory failure in Alzheimer's disease. Neuron 44:181-193

Wang J, Gallagher D, DeVito LM, Cancino Gl, Tsui D, He L, et al. Metformin activates an atypical PKC-CBP pathway to promote neurogenesis and enhance spatial memory formation. Cell Stem Cell 2012a;11:23-35.

Wang Q, Xu Y, Chen JC, et al. Stromal cell-derived factor 1a decreases $\beta$-amyloid deposition in Alzheimer's disease mouse model. Brain Res. 2012b;1459:15-26.

Wang X, Ma S, Yang B, Huang T, Meng N, Xu L, Li Q (2018) Resveratrol promotes hUC-MSCs engraftment and neural repair in a mouse model of Alzheimer's disease. Behav Brain Res 339:297-304

Wang Z, Peng W, Zhang C et al. Effects of stem cell transplantation on cognitive decline in animal models of Alzheimer's disease: a systematic review and meta-analysis. Scie. Rep. 2015; 5 (1): article 12134

Wernig M, Zhao JP, Pruszak J et al. Neurons derived from reprogrammed fibroblasts functionally integrate into the fetal brain and improve symptoms of rats with Parkinson's disease. Proceeding of the Nat Acad of Sci. U.S.A. 2008; 105: 15 (1)

Wu CC, Lien CC, Hou WH, Chiang PM, Tsai KJ. Gain of BDNF function in engrafted neural stem cells promotes the therapeutic potential for Alzheimer's disease. Sci. Rep.; 2016;6:27358. https://doi.org/10.1038/srep27358

Xin H, Li Y, Buller B, Katakowski M, Zhang Y, Wang X et al (2012) Exosomemediated transfer of miR-133b from multipotent mesenchymal stromal cells to neural cells contributes to neurite outgrowth. Stem Cells 30:1556-1564

Xuan AG, Luo M, Ji WD, Long DH (2009) Effects of engrafted neural stem cells in Alzheimer's disease rats. Neurosci Lett 450:167-171

Xue SR, Chen CF, Dong WL, Hui GZ, Liu TJ, Guo LH (2012) Therapeutic effects of human amniotic epithelial cell transplantation on doubletransgenic mice co-expressing APPswe and PS1 $\triangle$ E9-deleted genes. Sci China Life Sci 55:132-140

Yagi T, Ito D, Okada Y, Akamatsu W, Nihei Y, Yoshizaki T et al (2011) Modeling familial Alzheimer's disease with induced pluripotent stem cells. Hum Mol Genet 20:4530-4539

Yamasaki TR, Blurton-Jones M, Morrissette DA, Kitazawa M, Oddo S, La Ferla FM (2007) Neural stem cells improve memory in an inducible mouse model of neuronal loss. J Neurosci 27:11925-11933 
Yan Y, Ma T, Gong K, Ao Q, Zhang X, Gong Y (2014) Adipose derived mesenchymal stem cell transplantation promotes adult neurogenesis in the brains of Alzheimer's disease mice. Neural Regen Res 9:798-805

Yang CP, Gilley JA, Zhang G, Kernie SG (2011) ApoE is required for maintenance of the dentate gyrus neural progenitor pool. Development 138:4351-4362. https://doi.org/10.1242/dev.065540

Yang H, Xie Z, Wei L, Yang H et al (2013) Human umbilical cord mesenchymal stem cell-derived neuron-like cells rescue memory deficits and reduce amyloid-beta deposition in an ABPP/PS1 transgenic mouse model. Stem Cell Res Ther 4:76

Yang J, Li S, He XB, Cheng C, Le W (2016) Induced pluripotent stem cells in Alzheimer's disease: applications for disease modeling and cell-replacement therapy. Mol Neurodegener 11:39 https://doi.org/10.1186/s13024-016-0106-3

Yang Y-HK, Ogando CR, Wang See C, Chang T-Y, Barabino GA (2018) Changes in phenotype and differentiation potential of human mesenchymal stem cells aging in vitro. Stem Cell Res Ther 9:131

Ye L, Swingen C, Zhang J (2013) Induced pluripotent stem cells and their potential for basic and clinical sciences. Curr Cardiol Rev 9(1):63-72

Ylostalo JH, Bartosh TJ, Coble K, Prockop DJ (2012) Human mesenchymal stem/ stromal cells cultured as spheroids are self-activated to produce prostaglandin E2 that directs stimulated macrophages into an antiinflammatory phenotype. Stem Cells 30:2283-2296

Yoo J, Kim HS, Hwang DY (2013) Stem cells as promising therapeutic options for neurological disorders. J Cell Biochem 114:743-753

Yu B, Ma H, Kong L, Shi Y, Liu Y (2013a) Enhanced connexin 43 expression following neural stem cell transplantation in a rat model of traumatic brain injury. Arch Med Sci 9(1):132-138

Yu DX, Marchetto MC, Gage FH (2013b) Therapeutic translation of iPSCs for treating neurological disease. Stem Cell 12(6):678-688

Yuan SH, Martin J, Elia J, Flippin J, Paramban Rl, Hefferan MP et al (2011) Cellsurface marker signatures for the isolation of neural stem cells, glia, and neurons derived from human pluripotent stem cells. PLoS One 6:e17540

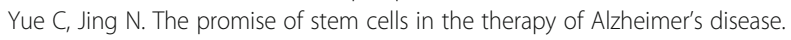
Transl Neurodegener. 2015; 4:8. Published 2015 Apr 28. doi: https://doi.org/ 10.1186/s40035-015-0029-x

Yun HM, Kim HS, Park KR, Shin JM, Kang AR, Lee K et al (2013) Placenta-derived mesenchymal stem cells improve memory dysfunction in an Abeta1-42infused mouse model of Alzheimer's disease. Cell Death Dis 4:e958

Zandi PP, Anthony JC, Khachaturian AS, Stone SV, Gustafson D et al (2004) Reduced risk of Alzheimer disease in users of antioxidant vitamin supplements: the Cache County Study. Arch Neurol 61

Zhagn L, Li Z (2014) Alzheimer and the discovery of Alzheimer's disease. Zhonghua Yi Shi Za Zhi 44

Zhang F, Jiang L (2015) Neuroinflammation in Alzheimer's disease. Neuropsyc Dis Treat 11:243-256

Zhang J Chopp M. Cell-based therapy for ischemic stroke. Expert Opin Biol Th. 2013;13(9):1229-40.

Zhang L, Tan X, Dong C, Zou L, Zhao H, Zhang X et al (2012) In vitro differentiation of human umbilical cord mesenchymal stem cells (hUC-MSCs), derived from Wharton's jelly, into choline acetyltransferase (ChAT)-positive cells. Int J Dev Neurosci 30:471-477

Zhang Q, Wu H, Wang Y, Gu G, Zhang W, Xia R (2015a) Neural stem cell transplantation decreases neuroinflammation in a transgenic mouse model of Alzheimer's disease. J Neurochem 136(4):815-825

Zhang W, Gu GJ, Shen X, Zhang Q, Wang GM, Wang PJ (2015b) Neural stem cell transplantation enhances mitochondrial biogenesis in a transgenic mouse model of Alzheimer's disease-like pathology. Neurobiol Aging 36:1282-1292. https://doi.org/10.1016/j.neurobiolaging.2014.10.040

Zhang W, Wang GM, Wang PJ, Zhang Q, Sha SH (2014) Effects of neural stem cells on synaptic proteins and memory in a mouse model of Alzheimer's disease. J Neurosci Res 92:185-194

Zhou Q, Brown J, Kanarek A, Rajagopal J, Melton DA (2008) In vivo reprogramming of adult pancreatic exocrine cells to beta cells. Nature 455:627-632

Zivin M, Pregelj P (2008) Prolonged treatment with donepezil increases acetylcholinesterase expression in the central nervous system. Psychiatr Danub 20

Zonari E, Desantis G, Petrillo C et al (2017) Efficient ex vivo engineering and expansion of highly purified human hematopoietic stem and progenitor cell populations for gene therapy. Stem Cell Rep 8(4):977-990

\section{Submit your manuscript to a SpringerOpen ${ }^{\circ}$ journal and benefit from:}

- Convenient online submission

- Rigorous peer review

- Open access: articles freely available online

- High visibility within the field

- Retaining the copyright to your article

Submit your next manuscript at $\boldsymbol{\sim}$ springeropen.com 